CAN YOU HOME AGAIN?

Desertion and Control

of Hometowns in Civil Wars

Theodore McLauchlin

$2011 / 34$

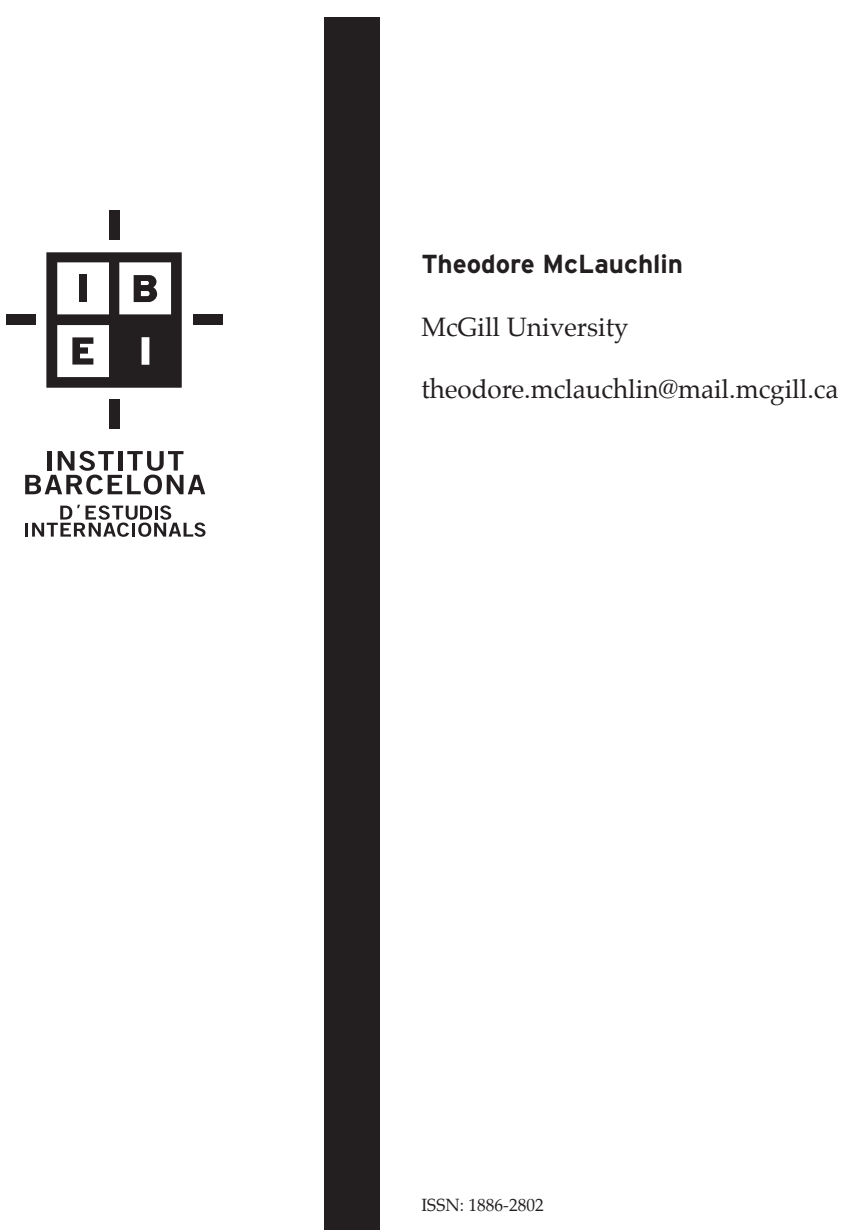




\section{IBEI WORKING PAPERS}

2011/34

Can You Home Again?

Desertion and Control of Hometowns in Civil Wars

\section{(C) Theodore McLauchlin}

(c) $\mathrm{IBEI}$, de esta edición

Edita: $\quad$ CIDOB edicions

Elisabets, 12
08001 Barcelona
Tel. 933026495
Fax. 933022118
E-mail: publicaciones@cidob.org
URL: www.cidob.org

Depósito legal: B-21.147-2006

ISSN:1886-2802

Imprime: CTC, S.L.

Barcelona, December 2011 


\title{
CAN YOU HOME AGAIN? DESERTION AND CONTROL OF HOMETOWNS IN CIVIL WARS
}

\author{
Theodore McLauchlin
}

\begin{abstract}
What allows an armed group in a civil war to prevent desertion? This paper addresses this question with a focus on control in the rearguard. Most past studies focus on motivations for desertion. They explain desertion in terms of where soldiers stand in relation to the macro themes of the war, or in terms of an inability to provide positive incentives to overcome the collective action problem. However, since individuals decide whether and how to participate in civil wars for multiple reasons, responding to a variety of local conditions in an environment of threat and violence, a focus only on macro-level motivations is incomplete. The opportunities side of the ledger deserves more attention. I therefore turn my attention to how control by an armed group eliminates soldiers' opportunities to desert. In particular, I consider the control that an armed group maintains over soldiers' hometowns, treating geographic terrain as an important exogenous indicator of the ease of control. Rough terrain at home affords soldiers and their families and friends advantages in ease of hiding, the difficulty of using force, and local knowledge. Based on an original dataset of soldiers from Santander Province in the Spanish Civil War, gathered from archival sources, I find statistical evidence that the rougher the terrain in a soldier's home municipality, the more likely he is to desert. I find complementary qualitative evidence indicating that soldiers from rough-terrain communities took active advantage of their greater opportunities for evasion. This finding has important implications for the way observers interpret different soldiers' decisions to desert or remain fighting, for the prospect that structural factors may shape the cohesion of armed groups, and for the possibility that local knowledge may be a double-edged sword, making soldiers simultaneously good at fighting and good at deserting.
\end{abstract}

Key words: Desertion; Defection; Military Cohesion; Civil War; Spanish Civil War 


\section{Introduction}

What allows an armed group in a civil war to prevent desertion? This paper addresses this question with a focus on control in the rearguard. Most past studies focus on motivations for desertion. They explain desertion in terms of where soldiers stand in relation to the macro themes of the war, or in terms of an inability to provide positive incentives to overcome the collective action problem. However, since individuals decide whether and how to participate in civil wars for multiple reasons, responding to a variety of local conditions in an environment of threat and violence, a focus only on macro-level motivations is incomplete. The opportunities side of the ledger deserves more attention. I therefore turn my attention to how control by an armed group eliminates soldiers' opportunities to desert. A few accounts of desertion study control in terms of hierarchy within armed groups, but here I consider the control that an armed group maintains over soldiers' hometowns. I find statistical evidence that the more easily controlled a soldier's hometown, the less likely he is to desert. Efforts to prevent desertion thus go well beyond the faction itself, and extend into civilian life.

This paper develops its argument via a statistical analysis of an original data set of desertion drawn from Santander province (now the autonomous community of Cantabria) in the Spanish Civil War. It combines characteristics of soldiers and of their hometowns in a multilevel model. The paper supplements the statistical analysis with qualitative evidence.

I examine control by focusing on terrain, especially steepness. Difficult terrain is difficult to police. While motivations may also vary by terrain, I demonstrate that, in my study area, the high desertion rates of difficult-terrain communities were not merely an artifact of differences in motivations. Net of motivation differences, and in light of considerable qualitative evidence, it appears that terrain has its impact through the most obvious of mechanisms: it is easy to hide in the hills, and deserters rely on their families and friends.

The paper concludes with the broader context. I propose replication of the finding in other micro-level settings, and two possible macro-level tests. This finding also opens new theoretical directions. It points up the importance of control of the rearguard and suggests some structural reasons why this control might vary. In turn, this suggests downstream implications for the process of negotiation between armed groups and rearguard communities: communities that cannot easily be controlled can negotiate for better terms. Moreover, in constructing an argument about terrain, I highlight the importance of local knowledge in facilitating desertion. This is a point that creates a potentially fascinating tradeoff: soldiers with good local knowledge may be both good at fighting and good at deserting. I suggest that the difficulty of knowing soldiers' motivations might be unpacked by examining ways in which those motivations can be revealed and constructed at the same time, in an endogenous fashion. Finally, the paper suggests a particular role for the periphery in civil wars: not as the source of insurgency but, potentially, as peripheral to the war itself. 


\section{Desertion, control, and hometowns}

This paper defines desertion as rule-breaking exit from military service, including both desertion proper (i.e. returning to civilian life) and defection (i.e. switching sides). ${ }^{1}$ Most past studies of desertion in civil wars, and a kind of shorthand conventional wisdom, focus on soldiers' motivations for deserting. In one approach, scholars begin with the large labels applied to civil wars-what Kalyvas calls the "master cleavage." ${ }^{2}$ They then characterize how soldiers stand with regard to that cleavage, and predict their desertion decisions from there. For example, in ethnic conflicts, some scholars predict the desertion of ethnic out-groups. ${ }^{3}$ Scholars may also focus on a lack of commitment to the cause, for example highlighting desertion in the Confederacy as a consequence of economic interests beyond slavery ${ }^{4}$ or a lack of socialization into Southern nationalism..$^{5}$ Another group of scholars takes more seriously Mancur Olson's collective action problem, ${ }^{6}$ pointing out that divergence from a grand, impersonal cause is hardly necessary to explain why a self-interested individual would choose not to support that cause. Even those who agree with a cause in principle may not agree to pay the personal costs associated with fighting for it. Armed groups may try to overcome this problem by providing soldiers certain positive inducements: cash payment, for example, or norms of cooperation among soldiers. Thus, though recruitment and not desertion is Collier and Hoeffler's focus, they do suggest that soldiers desert when economic opportunities are better outside of the army. ${ }^{7}$ In addition, drawing on classic works of military sociology that focus on soldiers fighting for their comrades, ${ }^{8}$ scholars focus on the social solidarity of the unit as providing reasons to stay and keep fighting. ${ }^{9}$ In particular, Costa and Kahn argue that Union troops in the US Civil War fought for each other; this cooperation was facilitated by homogeneity of hometowns, occupations and age groups within military units. ${ }^{10}$

The focus on motives has intuitive appeal, but there are theoretical difficulties with this approach. First, keeping analysis limited to motivations suggests that soldiers essentially have the freedom to act as they see fit. Costa and Kahn argue that in the Union Army, "most soldiers stood by their comrades even though a rational soldier would have deserted. Punishments were too rare and insufficiently severe to deter men from deserting." 11 This argument ignores important variation in the ability of armed groups to inflict such punishment. For example, on the Confederate side, efforts against desertion improved dramatically after General Gideon Pillow formed a special military branch to try to find deserters, rather than relying on the ill-equipped and undermanned Conscript Bureau. ${ }^{12}$ In any case there is a selection bias at work in using the capture rate of deserters as an indicator of the likelihood of punishment. If

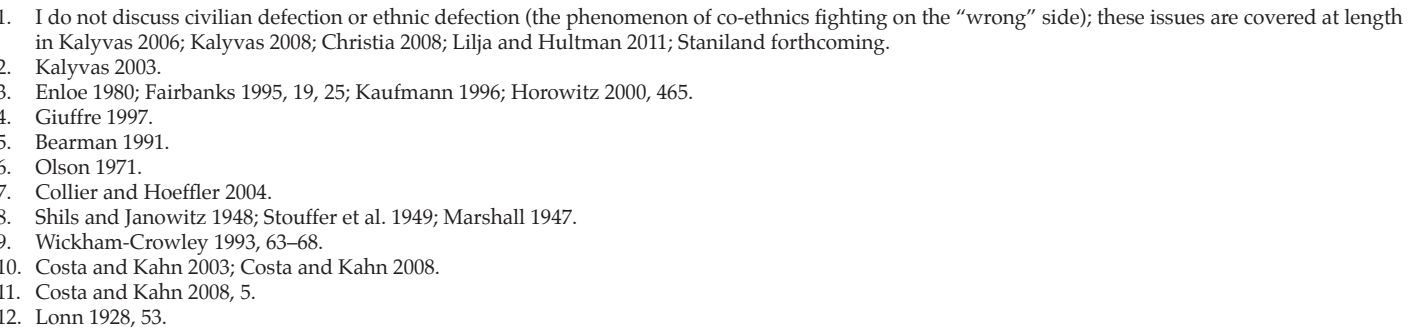


those who desert are those who anticipate that they are unlikely to get caught, and if that judgment is justified, there still may be many who fear punishment and never try to leave. Thus a low punishment rate among deserters may say very little about the overall degree of control that soldiers face. This critique of the motivations literature is similar to a recent more general critique of overly voluntaristic approaches to participation in civil wars: individuals do not participate out of free choice but in an environment of fear and coercion. ${ }^{13}$

A second theoretical difficulty is that motive theorists typically begin by assuming a core set of motives for soldiers: a grand cause that serves as a sort of scale for their degree of commitment, ${ }^{14}$ or a predominant motive, such as economic self-interest, that helps solve the collective action problem. But surveys indicate that soldiers fight for a variety of reasons, from ideology to community defense to personal gain; likewise, they desert for multiple reasons and in different conditions. ${ }^{15}$ In general, individuals in civil wars make decisions in response to a wide variety of fundamentally local conditions and locally-derived interests. ${ }^{16}$ Assuming away this diversity with strong assumptions about soldiers' motives may be an overly bold theoretical move.

Instead, the very variety of motives actually suggests the importance of control and coercion. In extremely close-knit armies-which must necessarily be quite small-it may be possible to get to know every soldier pretty well. To grow beyond this size, however, requires recruiting soldiers with highly diverse motivations that are difficult for an armed group's leaders to assess. Many of them may not share the armed group's aim at all. ${ }^{17}$ Heterogeneity means that it is hard for an armed group's leadership to tell when its soldiers are likely to defect. Control via monitoring and punishment of behaviour is a safeguard against desertion built on a lack of trust. Whatever the soldier's motivations, desertion can be prevented or deterred by watching soldiers' behaviour closely and threatening punishments that anyone would try to avoid.

Control can be a matter of hierarchical military organization, trading on features like the structure of an army, the autonomy that subordinate military units have, and the physical distance between the armed group's command and it soldiers. ${ }^{18}$ But control can also be exercised over soldiers' hometowns, and the degree of control that the faction exercises can have a strong influence on a soldier's opportunities to desert. First, deserters often head back to home districts as a matter of first resort, relying on families or friends for help and support, including shelter and food. Second, deserters' families often bear punishment for their desertion. This makes sense, since if a deserter is not himself caught, an armed group may decide to resort to other coercive tools at its disposal, creating a deterrent. The punishment of families also means that

13. Kalyvas and Kocher 2007

14. DeNardo (1985) makes this scale explicit in a theoretical analysis of social movement activists.

15. Arjona and Kalyvas 2006; Humphreys and Weinstein 2004; Peters and Richards 1998.

16. Kalyvas 2003.

17. Weinstein 2007; Mueller 2000; Kalyvas 2006.

18. Gates 2002; Johnston 2008 
hometowns are important for defection-i.e. side-switching-as well as for desertion proper, back to the rearguard; if a soldier defects, his family can still be punished. That threat may be more or less credible depending on the control the armed group has over the soldier's hometown.

Factions vary in their ability to control the rearguard. What factors help ensure local control? There may be a role for positive cooperation. Armed groups in civil wars may vary in the degree to which they have cooperative relationships with civilians, as Jeremy Weinstein argues. Such cooperation can provide armed groups with various different kinds of support, including supplies, information, and shelter. ${ }^{19}$ And it can also help with the finding and capture of deserters. In the US Civil War, for example, the civilian population on the Union side bought in to the cause, such that deserters faced social sanctions rather than social rewards when they returned home. ${ }^{20}$

However, beyond cooperation, finding deserters may be a matter of monitoring and coercion. Patterns of cooperation may in fact be partially contingent upon the patterns of territorial control exercised by the different sides of the civil war's "master cleavage": where one side's control is uncontested, civilians are much more likely to comply than where control is in dispute. ${ }^{21}$ I extend Kalyvas' insight on this point to the issue of internal control within the state-like entities controlled by armed groups in civil wars. ${ }^{22}$ Where Kalyvas focuses on problematic control predicated on competition with another armed group, I abstract from contestation with the other side. I focus on variation in control that still occurs where the other side does not pose a serious threat. This internal control is analytically distinct from the problems of control that competition with the other side creates. I argue that, just as states can vary in their ability to compel citizens' compliance, ${ }^{23}$ armed groups in civil wars can vary as well.

In this paper, I explore geography, specifically difficult terrain, as an important structural attribute shaping patterns of local control. It has historically been quite difficult to exercise control over mountainous locations. It is, of course, easier to hide in the folds of the earth than on flat land.${ }^{24}$ In addition, the classic loss-of-strength gradient, based on the difficulty of transporting men and supplies over distance, ${ }^{25}$ is compounded by the friction of terrain. ${ }^{26}$ Thus heading to the hills is a ubiquitous feature of desertion. Confederate deserters hid in bands in the hills to resist capture. When the Confederate War Office was analyzing the problem of desertion, it noted that "the condition of things in the mountain districts of North Carolina, South Carolina, Georgia, and Alabama menaces the existence of the Confederacy as fatally as either of the armies of the United States." ${ }^{27}$ Similarly, civilians have frequently headed to the

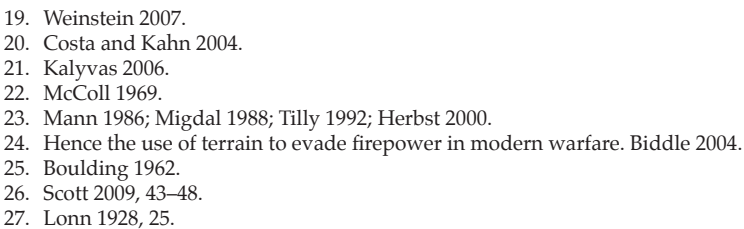


hills to avoid the depredations of warfare. In massive numbers, civilians in Southeast Asia long fled conscription and the pillaging of marauding armies by fleeing to the hills, and many still do in response to Myanmar's counterinsurgency campaign against the Karen..$^{28}$ The increasing ability to cross rough terrain, especially through road-building, is therefore a vitally important part of state-building conceived of as the projection of control of peoples over distance. ${ }^{29}$

Those best able to take advantage of the opportunities to hide should be those who are actually from hill communities. So, for example, Giuffre finds that soldiers from the piedmont of inland North Carolina were more likely to desert than soldiers from the coastal plains. ${ }^{30}$ Unlike Giuffre, who focuses on hill peoples' detachment from the cause of slavery, I argue that high desertion rates among highland peoples stem from their ability to escape control. Possessing an unparalleled local knowledge of the terrain, soldiers from the mountains will be able to exploit the opportunities for physical concealment that mountains provide. In addition, the defensive advantages of mountain communities mean that they are likely to be politically autonomous; deserters may therefore be able to gain help from cooperative local officials who have stronger incentives to help deserters than they do to follow the orders of the armed group's command.

\section{The Setting: Santander Province, Spain}

Santander province in the Spanish Civil War is an appropriate research setting in which to investigate a control- and opportunity-based explanation for desertion in the face of a conventional wisdom based on motivations. The historiography of the war is dominated by two basic themes: the master cleavage of left and right, and the problems of forging centralization and control on the left-wing or Republican side. Within that context, the high desertion rate in Santander is generally understood in terms of the first theme: as the result of a mismatch between the left-wing cause and that province's conservatism.

The Spanish Civil War is easily treated as an elemental clash of left-wing and right-wing ideologies in the context of a broader European contest among fascism, communism and democracy. ${ }^{31}$ Fought in the three years prior to the Second World War, it pitted a tense Popular Front coalition of Left Republicans, Socialists, Communists and Anarchists in defense of the incumbent Second Spanish Republic against a right-wing "Nationalist" rebellion drawing on junior military officers, monarchists supporting different pretenders, and the fascist Falange party. On the Republican

28. Scott 2009, 94-95, 146-149.

29. Herbst 2000

30. Giuffre 1997

31. This account of the Spanish Civil War draws on Alpert 1989; Beevor 2006; Bolloten 1991; Cardona 2006; Carr 1977; Graham 2002 ; Preston 2007 (probably the best short introduction); Thomas 1994 . 
side, after the failed coup attempt of 18 July 1936 that began the war, the sections of the army that remained loyal were supplemented by a large array of autonomous militias formed by political parties and unions. This was a disorganized and frequently fractious force. The process of uniting it into a hierarchical and coherent whole began in the autumn of 1936, met considerable resistance and only really ended by May of 1937.

The map of Spain was divided between these two camps. Republican territory was itself split too, with the bulk stretching from the Mediterranean coast through Madrid in the centre, and a strip of land along most of the northern coast from Asturias through to the Basque Country that was cut off from the rest as of September 1936. Nationalist offensives brought Madrid under siege by November of 1936, and, beginning with the siege of the capital, from that point the war in much of Spain bogged down into slow, bloody manoeuvres along stable front lines. But the Nationalists were able to mount steady offensives; the northern strip of Republican territory fell over the course of 1937, after which Franco then turned his attention to the remainder. Over the course of the next two years, the Nationalists steadily took Republican territory and by April of 1939 the Republic was thoroughly defeated.

\section{Figure 1. Location of Santander Province in Spain}

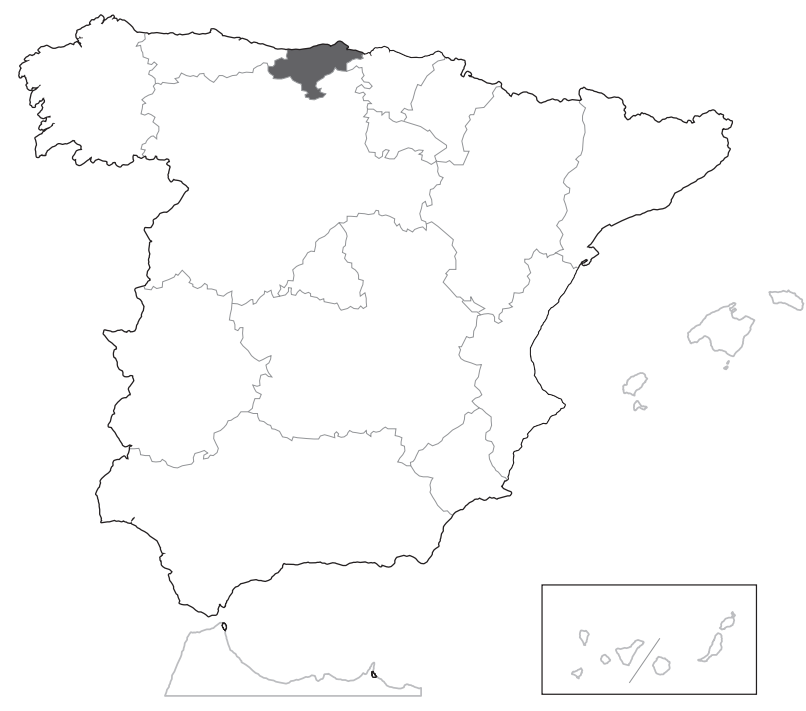

This paper focuses on Santander province (now Cantabria), between Asturias to the west and the Basque Country to the east on Spain's northern coast (see Figure 1). ${ }^{32}$ Cut off by the Nationalist zone from the bulk of the Republic, Santander developed an autonomous government and war effort, as did the Basque Country and Asturias next door. However, unlike the other two areas, Santander's war effort followed the 32. The following account draws on Salas Larrazábal 1973; Saíz Viadero 1979; Martínez Bande 1972; Martínez Bande 1980; Solar 1996; Solla Gutiérrez 2005;
Solla Gutiérrez 2006. 
Republic's policies rather closely. Beginning with a loose militia system based on political parties and the remnants of the uniformed security forces that remained loyal to the Republic, it gradually developed a regular, conscripted army, the Cuerpo de Ejército de Santander (CES). In this, the autonomous government followed the letter of the directives laid down by the capital. Moreover, its formal political forces closely mirrored those of the Republic in general in the period 1936-1937, with a Socialistdominated government; an uneasy partnership with a weaker but still highly active Anarchist presence; and a small but rising Communist Party whose increasing political strength raised suspicions among the other factions. As elsewhere, political power fragmented among local committees at first, and it was a long and difficult process to reassert it at the centre. In some ways, therefore, Santander province was the Republic in miniature.

But in one vital respect it was wholly different from much of the Republic: the prewar strength of conservative political forces. Of all Spain's provinces that were part of the Republic, Santander had returned the one of largest proportions of votes for right-wing parties, and in fact a right-wing majority, in the elections of February 1936. ${ }^{33}$ And it had a weaker union presence than most other Republican provincescertainly much less than the key union centres of Madrid, Barcelona and Asturias. Despite its conservatism and the weak presence of organized left-wing forces, it was kept for the Republic because of a series of fortuitous circumstances, notably much greater initiative among Republican officers during the coup attempt.

After the coup attempt, a stable and relatively quiet front was quickly set up on Santander's southern frontier. Initially the Republican fighting was done by volunteer militias, but over time they were centralized into the CES, which instituted a draft in fall 1936. The stability of the front was punctuated by Republican offensives to relieve the siege of Madrid in November 1936, offensives which stalled easily as Santander soldiers began deserting frequently. The northern front stabilized until April of 1937, when the Nationalist forces, with their Italian and German allies, carried on with the conquest of the Basque Country. Meanwhile, Santander troops conducted another failed attack; again, its offensive was plagued with desertion. Bilbao, capital of the Basque Country, fell at the end of June; at this point it was only a matter of time before Santander faced a Nationalist invasion. This began in mid-August and was over within two weeks: the CES' resistance collapsed in the face of the assault. Some CES forces remained in Asturias to fight on until October; others took to guerrilla warfare, which lasted sporadically until the late 1950s; but most surrendered.

The conservatism of Santander province makes it a most-likely case for a motives approach to desertion. Though reliable overall figures on desertion rates in Spain do not exist, Santander province is generally acknowledged to have among the highest. The province's conservatism is the most frequent explanation, offered

33. Linz and de Miguel 1977, 43. 
both by the Left and the Right. This is a claim made both by Republicans and Nationalists: by the last Republican commanding officer in the north, General Mariano Gámir Ulibarri, and by the pro-Franco historians Salas Larrazábal and Martínez Bande. ${ }^{34}$ In the Spanish context, Santander is strong ground for a motivations story. There was a poor fit between the political attitudes of the population and the side of the master cleavage that the province was called to fight for. If there is support, here, for an approach based instead on control and opportunities, then that support should be particularly telling.

\section{Hypotheses and control variables}

\section{Figure 2. Estimated Rate of Desertion by Municipality (\% of soldiers), Santander Province}

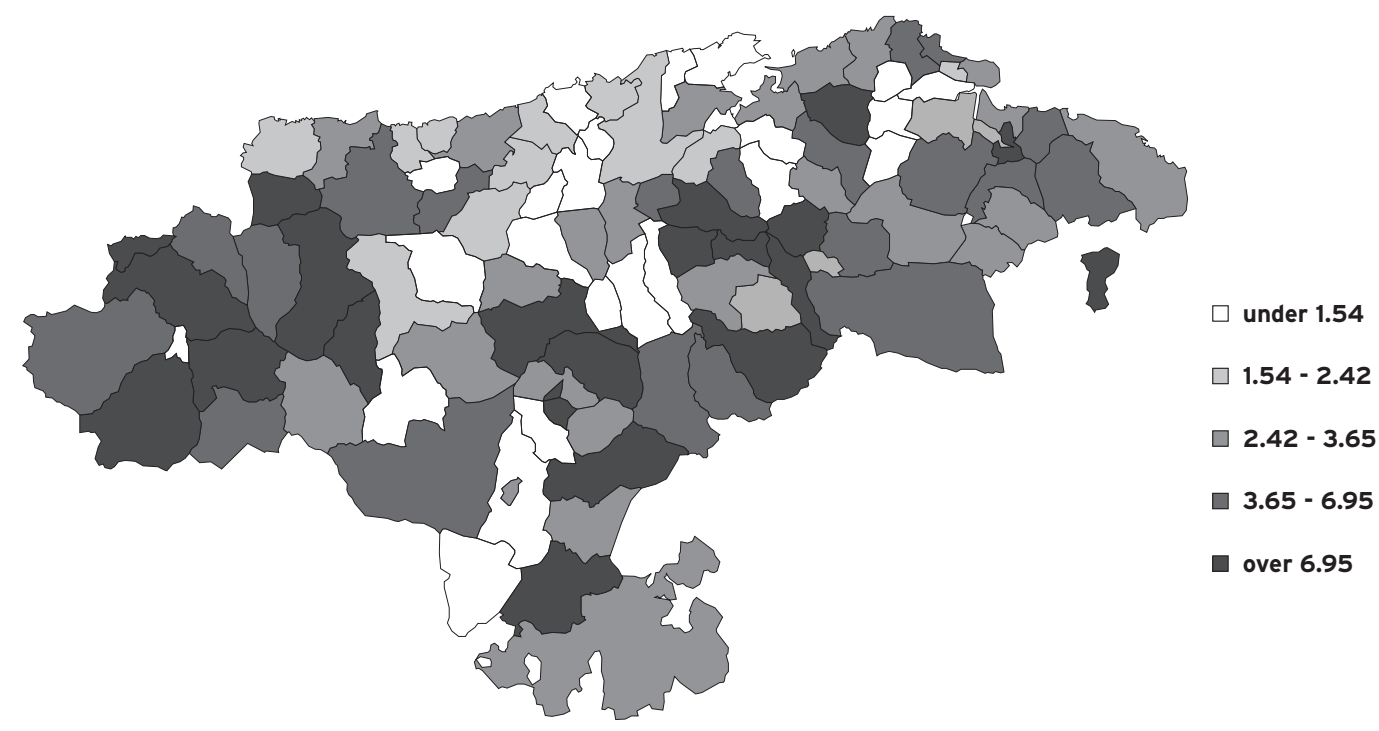

Results are given by quintiles. Source: author's data

Over the course of this fighting, desertion rates varied widely by soldiers' hometowns. Figure 2 maps the estimated rate of desertion from my data-deserters divided by the weighted estimate of soldiers from the same municipality. What explains this variation? I suggest that an important reason why municipalities varied in desertion rates is that the CES varied in the degree to which it could impose its control on those municipalities.

A challenge in measuring the degree of control over different municipalities

34. Gámir Ulibarri 1939, 37; Salas Larrazábal 1973, 358-359; Martínez Bande 1980, 153, 167. 
is that, in some respects, this control is likely to be endogenous to desertion. This is particularly true of the numbers of security forces able to search for deserters in a particular location. Obviously, the faction is likely to deploy its security forces where they are needed: to locations that are particularly problematic in terms of desertion. Reports of large groups of deserters, such as an April 1937 report of twelve deserters from the municipalities of Solórzano and Entrambasaguas, would lead to the deployment of security forces for a search (in this case, by a unit of twenty). ${ }^{35}$

I turn instead to a strongly exogenous factor in control over a hometown: its terrain. I measure this with two indicators: altitude and steepness. Centres of power are often located on low ground, and this was certainly the case in Santander province, with its capital in Santander city on the coast and with its left-wing Socialist-dominated government based in its lowland industrial core. Altitude implies difficult access from a lowland base, increasing transportation costs and thus the costs of projecting power over distance. Steep terrain measures more localized sources of difficulty in using force, abstracting from the cost of moving from a lowland core to the highlands and operating within the highlands themselves. Steep terrain can create places to hide, and makes transportation even more costly. As I outline above, my chief interpretation of terrain is its ability to allow deserters and their families to evade capture. I therefore hypothesize that the higher the altitude and steeper the terrain of a soldier's home municipality, the higher his likelihood of desertion.

Of course, communities on the geographic periphery may often have very different social, economic, and political conditions than the centre. Terrain may therefore be associated with desertion rates not because of opportunities to desert, but because people's economic and political preferences differ substantially over terrain. On the geographic margins, people may believe that the civil war is just not their fight; it is driven instead by lowlander agendas. This is Giuffre's argument in attempting to account for higher desertion rates in North Carolina hill country. ${ }^{36}$ If true, this would tend to support a voluntarist, motives-based approach and not an approach based on control and opportunity. Indeed, in Santander province, the development of the late $19^{\text {th }}$ and early $20^{\text {th }}$ century was very much concentrated in the lowlands: in the ports of Santander and Astillero and the surrounding mining basin. Although railroads permitted closer integration of rural communities into the broader economy, with the shipping of livestock and cattle ${ }^{37}$ many mountainous areas did not have easy access to highways or railroads. ${ }^{38}$ Since mining and industry, the two major early targets of left-wing unionization, were relatively uncommon in mountainous districts, the Left had little political appeal. ${ }^{39}$ The Socialists' efforts to unionize agriculture were belated and of limited success. ${ }^{40}$ In addition, the strong presence of the Catholic Church in mountain districts kept up support for the Right.

35. Radio Comunista de Secretario Político and Agrupación Socialista de Riaño to Frente Popular Santander, 30 April 1937. Centro Documental de la Memoria Histórica [CDMH], Salamanca, Serie Político-Social [PS] Santander L, caja 412, carpeta 22, expediente 22.

36. Giuffre 1997.

37. de Puente Fernandez 1992

38. Obregón Goyarrola 2007, 30-31.

39. Gutiérrez Lázaro and Santoveña Setién 2000; Toca 2005.

40. Obregón Goyarrola 2007, 36-37. 
These characteristics indicate the importance of controlling for economic development and political support. Literacy rates indicate the degree of development in different areas, since literacy reflects educational opportunities and enables a wider array of economic activities. According to the 1930 census, literacy varied quite substantially by municipality in Santander, from under 50\% to over $80 \%$; the rate for the whole province was 72\%. ${ }^{41}$ The vote share for right-wing parties in the February 1936 elections (five months before the start of the war), is a straightforward indicator of the degree of local political opposition to the Republican cause.

Economic and political marginality could be considered indicators of a lack of control in the sense of infrastructural power ${ }^{42}$ or the presence of the organizational arm of political parties. However, such marginalities cannot stand on their own as evidence of my opportunities story, because they are both also consistent with a theoretical perspective focused on motives rather than on opportunities. I therefore examine literacy rates and political support for the Right as control variables for the major hypothesis about geography. If high altitude and steep terrain have a substantial correlation with desertion even after controlling for these two variables, it indicates that terrain has a relationship with desertion goes beyond its association with people's motives. I suggest, then, that the best explanation is the most intuitive one: that rough terrain makes it easier to hide.

Finally, an indicator of lack of control may be the local rate of violence. This is fundamentally ambiguous, however: lack of control can allow for more violence to occur, or violence could be the result of an attempt to impose control on a place. Cohen, Brown and Organski capture this ambiguity by terming state building "the violent creation of order"; they find, at a macro level, that state building produces violence in the first instance but long-run order once the state is well-established. ${ }^{43}$ In the Spanish Civil War, it is often argued that violence against civilians on the Republican side was the consequence of lack of control over undisciplined militias (incontrolados). ${ }^{44} \mathrm{How}-$ ever, systematic analysis is somewhat ambiguous on this point. Balcells, in a statistical study of violence in Catalonia, finds that rates of local violence were correlated with pre-war political competition, so that closer election results predicted higher rates of violence. ${ }^{45}$ This may indicate the pursuit of local rivalry and competition outside of the Republican leadership's interests, and hence a lack of Republican central control; or, from another point of view, it may indicate efforts to eliminate the opponents of the left, and hence an attempt to reassert control. Because local violence may be an ambiguous indicator of state control of a location, I include a measure of local violence as an exploratory project, rather than to test a theory-derived hypothesis.

Soldiers from rough-terrain communities may also desert less often because of differences in individual characteristics. They may be less likely than their lowland comrades to want to serve in the first place. They may more frequently be agricultural

\footnotetext{
41. Dirección General del Instituto Geográfico, Catastral y de Estadística 1930.

42. Mann 1986.

43. Cohen, Brown, and Organski 1981.

44. Beevor 1982, 106-107.

45. Balcells 2010 .
} 
workers, with their families depending on them for survival. Rural soldiers may be more likely to be married and to feel the pull of home more strongly than others. I conduct a multilevel analysis, therefore, to control for these individual characteristics systematically. I examine soldiers' circumstances of joining up-whether as a volunteer or as a conscript, and the date of joining - as a useful indicator of a general preference for serving. Whatever the soldier's reason for wanting to fight or not fight, such a motivation will likely be captured in his willingness to join up voluntarily in the first place. A soldier's conscription status thus serves as a proxy for a wide array of latent motivations. Whether or not a soldier has an official party or union affiliation may also indicate his general degree of political commitment to the left. I also include age, marital status, and occupational category, to capture several demographic characteristics occasionally thought to correlate with a propensity to desert. ${ }^{46}$

\section{Potential biases from case selection}

\section{Figure 3. Relief Map of Santander Province}

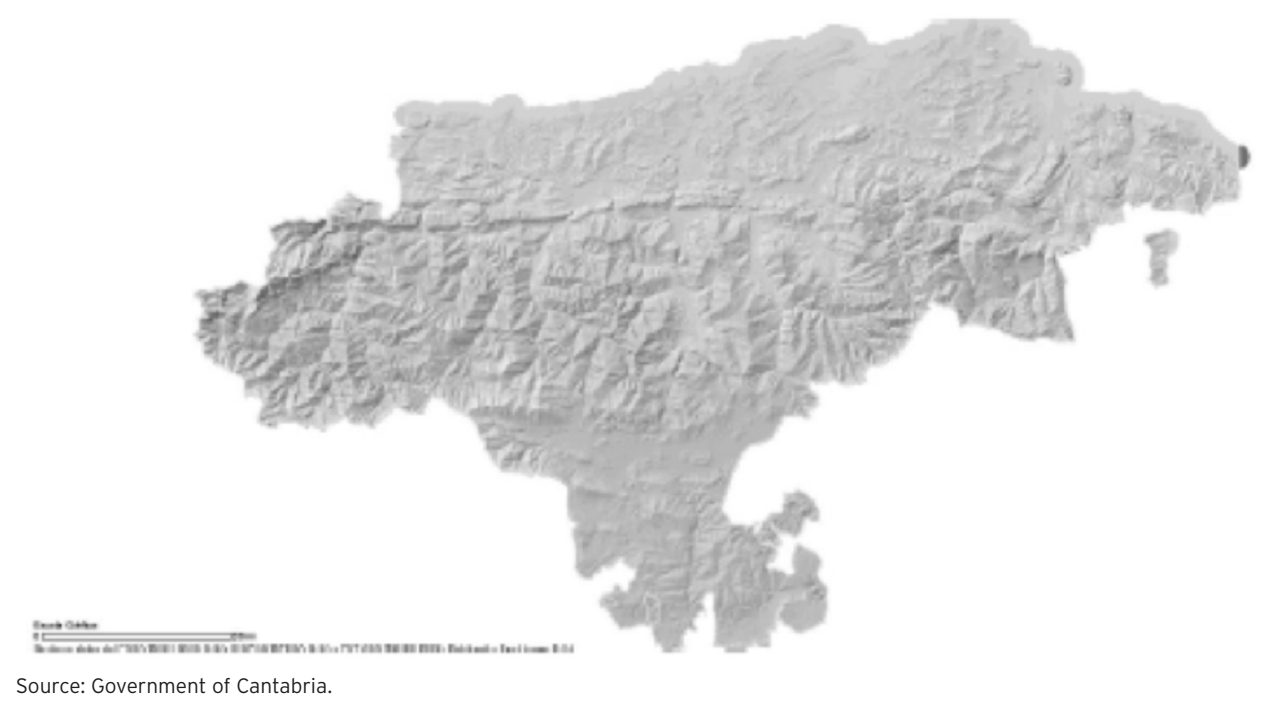

The geography of Santander may suggest some biases in case selection. The dynamic of coastal core and mountainous periphery is particularly pronounced in Cantabria (see Figure 3). The geography of the province ranges from coastal plains to high cordillera. Moreover, as indicated, the heart of the Republican support in Santander province was the capital and towns in the lowland industrial centre. This suggests

46. Bearman 1991; Costa and Kahn 2003 
the classical pattern of a lowland state ruling over a mountainous periphery. ${ }^{47}$ It is possible that a faction rooted in the mountains themselves may not have as much difficulty controlling highland dwellers. However, the pattern of lowland authority and highland periphery is common enough because of the wealth and power of lowland urban cores that this analysis should be applicable fairly widely. Within Republican territory alone, the pattern also holds for Catalonia and Aragón, for instance. As well, even where authority emerges from the mountains themselves, it tends to be very limited in geographic scope because of the difficulty of transportation..$^{48}$ Therefore, even when armed groups emerge from the mountainous periphery itself, they may have considerable difficulty in controlling territory and preventing desertion. If the relationship between terrain and desertion is due only to a dynamic of lowland rule over highland areas, we should expect local steepness of terrain to make no difference in desertion rates when controlling for altitude above sea level: altitude should capture the lowland-rule dynamic, while steepness captures more municipality-bymunicipality variation in the ease of using force.

As well, much of mountainous terrain in Santander province is located along the province's borders with Nationalist-held Palencia and Burgos provinces. At the beginning of the war, civilians were able to take to the hills to cross the lines before they even got in to the army, removing them from the ambit of the army and thus from my dataset. ${ }^{49}$ On the one hand, this may suggest that some high-altitude soldiers were not going home when they deserted but crossing the lines to reunite with families who had already switched sides-indicating a strong motive. This would not necessarily challenge the broad theory at stake, because it is also a scenario in which a soldier's family is out of the faction's control. In any case, this selection effect may actually produce a conservative bias, because the analysis would understate the potential impact of hills on desertion. Those soldiers from high-altitude regions who remain to be included in my dataset are those who decided not to switch sides at the outset of the war, and thus likely have a lower than average motivation to try to evade military service. The possibility of evasion at the start of the war thus actually lowers the likelihood that terrain picks up the effect of motivation rather than opportunity.

\section{Data and Method}

The focus of this paper, on soldiers' hometowns, would perhaps be best treated with a hometown-by-hometown sampling method. However, this proved impractical. No complete set of hometown-by-hometown lists of soldiers exists, and so there was no real basis for sampling this way. Instead, therefore, I decided to sample on individuals.

47. Scott 2009 .

48. Ibid

49. García Guinea 2005; Obregón Goyarrola 2007. 
Data on deserters and other soldiers were obtained from the archives located in the Centro Documental de la Memoria Histórica, formerly the Archivo General de la Guerra Civil, in Salamanca. I began by identifying deserters on the basis of army records. The army used the following definition of a deserter: a soldier who failed to appear for three consecutive roll calls without leave. Where a subsequent report indicated that the initial report was in error-for example, a leave unreported because of a failure in communication - the individual in question was excluded.

I identified deserters from three kinds of document. First, the army compiled lists of deserters' names, by battalion and month, beginning with a retrospective list in February 1937 that went back to November 1936, and continuing in each subsequent month; the last set of lists was created in July $1937 .{ }^{50}$ Second, beginning in January 1937 , the army produced individual reports of desertion, including the deserter's name, background details, and circumstances of desertion. The preservation of these reports is unfortunately highly inconsistent: only those with last names beginning A through $\mathrm{L}$, and scattered others, are preserved. ${ }^{51}$ Finally, the army produced a card for each of its soldiers indicating his background information. These cards also included notes on his subsequent military career, such as battalion reassignments, leave, hospital visits, and desertion. I compiled every soldier with a desertion report in all of the over 32,000 army cards that have been preserved. Unlike the deserter files, these cards appear to have no serious inconsistency in preservation, aside from under-sampling some military units. ${ }^{52}$ There were other deserters that are not included here. Scattered and disorganized military reports refer to reported deserters who are not elsewhere referenced. As a particularly unfortunate example, one report from the municipality of Miera indicated a list of 7 men reported by their battalion to have deserted; only two of them had files and could be included in my dataset..$^{53}$ There are also numerous ambiguous cases. For example, there is a case of a soldier from Battalion 130 who disappeared and, after a long paper trail, could not be found..$^{54}$ Time did not allow for a systematic accounting of each of these, unfortunately. A further, more labour- and time-intensive effort is needed to compile a more definitive list of deserters in Santander province.

To preserve as much information as possible about deserters, I included every deserter as defined above, totalling 1,313. This almost certainly understates the true number of deserters. In addition, I took a simple random sample of 1,305 of the remaining personnel files. ${ }^{55}$ The individuals were given corresponding probability weights.

There are at least two validity concerns with this approach to desertion. The first arises from the time period covered by the data. Reports of deserters only really begin in earnest in January 1937. This means that anyone who joined and deserted prior to that date is not captured by my approach. Therefore, any volunteers who remain from the "militia period" have already failed to desert on multiple prior occasions that are not

50. CDMH, PS Santander A, caja 180, carpeta 7; CDMH, PS Santander A, caja 190, carpeta 4.

51. CDMH, PS Santander C, caja 26, carpetas 1-4; CDMH, PS Santander M, caja 7, carpeta 12; CDMH, PS Santander A, caja 188, carpeta 4.

52. The large bulk of these files are contained in $\mathrm{CDMH}$, PS Santander A, cajas 1-72.

53. CDMH, PS Santander L, caja 444, carpeta 13 , expediente 19

54. CDMH, PS Santander L, caja 412, carpeta 20, expediente 21

55. King and Zeng 2001. 
captured in my analysis. Volunteers in my data set should thus be particularly unlikely to desert. This should exaggerate the differences between conscripts and volunteers. In addition, the Santander Army Corps crumbled in the face of Nationalist offensives over the course of about one week in late August 1937. Because reporting would have become unreliable at the same time, the wave of desertion that apparently occurred is not captured either. My data then capture desertion during a relatively stable period, January to mid-August 1937. There is reason to believe that desertion may operate differently in a cascade such as at the end of August, with soldiers responding endogenously to the prospect of defeat. ${ }^{56} \mathrm{My}$ data thus cannot speak to those situations.

A second validity concern with this measure of desertion arises from the incentives of those doing the reporting. A commander may have had an interest in telling the General Staff what it wanted to hear. For example, commanders would have wanted to report that desertion rates were low, which may account for the surprisingly low figure of 1,313 deserters, a rate of about $4 \%$, compared to anecdotal evidence that suggests a much higher rate. An underreporting bias certainly existed at a high level: General Toribio Martínez Cabreras, serving in the North at the time, reported to the Republican government on 15 July 1937 that in Asturias and Santander, "despite certain problems of political order," the armed forces, now provided with regular leadership and organized into regular units, "improve each day at responding to norms of discipline." ${ }^{57}$ This statement was not at all true of desertion in Santander: in the month in which it was written, according to my data, desertions had steadily increased in frequency and were at a peak. In and of itself, the tendency to underreport desertion does not immediately suggest a systematic bias in the data, just that the baseline rate of desertion was lower than true, and that some members of my sample of non-deserters may actually have deserted. ${ }^{58}$

A graver concern, since it deals with validity and not just reliability, is that commanders might also have wanted to report that the profile of deserters was as the General Staff expected it to be. If, for example, the General Staff saw hidden rightwingers as the major problem of desertion, then it would find right-wingers who deserted unsurprising. But this would also imply that a report of the desertion of a good party comrade would reflect badly on a commander who could not even keep those individuals in line. The commander's career could then be jeopardized. He would therefore be inclined to quash such a report: either to not deliver it at all, or to report some other reason why the soldier was not present to be reviewed: a "disappearance," for example. This is a plausible logic, and it suggests that the picture of deserters may be artificially biased in favour of the army's conventional wisdom. That conventional wisdom did include the stereotype that soldiers from mountainous communities-in particular, the Pasiego nomadic-pastoralist group-deserted frequently. However, the conventional wisdom was much more dominated by the idea that soldiers deserted because they were not attached to the cause, or because they were particularly fearful.

\footnotetext{
56. McLauchlin 2010.

77. General Toribio Martínez Cabreras, "La Lucha en el Norte," Valencia, 15 July 1937. Archivo General Militar de Ávila [AGMAV], Documentación de la República [DR], Armario 63, Legajo 853, Carpeta 7, Documento 4, pp. 27-28.

58. This underreporting of desertion is found in other cases as well, such as the Confederacy. Weitz 2005
} 
There may be a countervailing bias from reporting as well, however. The CES pursued various policies in an attempt to constrain those soldiers who were thought likely to desert. If such a soldier deserted, it might raise uncomfortable questions about why that soldier was not under sufficient vigilance in the first place. Consider the case of one soldier from Battalion 115 who deserted on 27 July 1937. An apparent right-winger with no official political affiliation, he had been placed under "discreet" watch by the captain of his company; the report says that he was able to defect to the Nationalist front because there were only two sentinels on duty that night since it was an unimportant front. ${ }^{59}$ This suggests an effort to determine how a likely deserter had been allowed to escape, casting aspersions on his immediate superior's abilities. Therefore, there is reason to expect a counter-bias from commanders' reports: the inclination to under-report unsurprising desertions, because unsurprising desertions might be taken to mean that the commander was negligent. The prospect of validity problems from reporting is, therefore, inconclusive.

Soldiers' hometowns were given on their files. I classified these hometowns according to the 102 municipalities in Santander province. I include only soldiers from within Santander province ( $92 \%$ of the total), because data on steepness were only readily available for it, and because my hypotheses really only apply to the direct ambit of the Santander regional government. I examined two measures of terrain: altitude and steepness. Altitude is defined as the altitude of the municipal seat in meters above sea level. For steep terrain, I constructed an index. There are data available for all but two of Santander's municipalities (the geographic survey is not yet complete) on the proportion of the municipality's terrain that is between 30 and $50 \%$ in grade, and the proportion greater than $50 \%$. I combined these two measures in a single index of steepness, defined as follows:

$(0.3 *$ proportion of territory $30 \%$ to $50 \%$ in grade $)+(0.5 *$ proportion $>50 \%$ in grade $)$

The data are given by the Instituto Cántabro de Estadística. ${ }^{60}$ The municipalityby-municipality results of the February 1936 elections were published in the Boletin Oficial de la Provincia de Santander.$^{61}$ Literacy data are drawn from the 1930 census. ${ }^{62}$

Data on local violence were compiled by Jesús Gutiérrez Flores ${ }^{63}$ They indicate the number of deaths in local violence against individuals residing in the municipality. This means that a death was attributed to a community even if it did not occur there; according to Gutiérrez Flores, much of the violence in Santander province during the Civil War took place with kidnappings and executions elsewhere. The seizure itself of an individual, however, is quite relevant: it indicates the effort to eliminate an individual from a community, wherever the person's execution ultimately took place. To construct my measure of local violence, I divided this number of deaths by the total population ac-

\footnotetext{
59. Oficial Informador, Batallón 115, to Jefe Sección Información Santander, 30 July 1937. CDMH, PS Santander L, caja 412, carpeta 16, expediente 1.

60. Instituto Cántabro de Estadística 2009.

61. Boletín Oficial de la Provincia de Santander, 26 February 1936

62. Dirección General del Instituto Geográfico, Catastral y de Estadística 1930.

63. Gutiérrez Flores 2006
} 
cording to the 1930 census. I limited the violence measure to the period prior to January 1, 1937, because desertions were only measured in earnest after that point; this allows me to avoid potential problems of endogeneity arising from the use of violence in efforts to capture deserters and punish their families. And, of course, I remove any executions at the front, since this would tend to be quite endogenous to desertion.

Data on conscription versus voluntarism were gathered from the card's indicator Soldado o miliciano - soldier or militiaman. This indicates whether the soldier was a member of the ad-hoc volunteer militias that had emerged at the beginning of the war, or was regularly incorporated via the draft. Political affiliations were also listed on the card. A left-wing affiliation was defined as follows: indicated membership in one of the two large unions, the Socialist UGT or the anarcho-syndicalist CNT, or affiliated unions; in a Left Republican party (the Izquierda Republicana and the Unión Republicana), the Socialist party, the Communist party, the anarchist FAI, or the joint Socialist-Communist youth wing, the JSU. Non-membership was often indicated explicitly (e.g. "ninguna" or none), but soldiers were also coded as unaffiliated if there was a line drawn through the cell for political affiliation. The reason is that the field was often left blank; if it was truly unknown, then, the clerk could leave it as it was. (For obvious reasons, no-one was listed as having a right-wing affiliation.)

Occupational codings were quite difficult. I broke down the sample into different economic sectors: day-labourers and unskilled workers; yeomen farmers (labradores); miners and industrial workers; service-sector workers (other than businessmen and professionals); students; and a combined business-professional category. I broke down occupations in this way in order to capture broad income categories. In line with Collier and Hoeffler's argument that soldiers should desert when better economic opportunities exist outside the army, ${ }^{64}$ attempted to estimate the effect of wages directly by drawing on contemporary government data on industrial wages ${ }^{65}$ and Bringas Gutiérrez's data on agricultural wages, gathered from the Spanish Statistical Yearbooks ${ }^{66}$ but this was a questionable approach. The base of information for industrial wage rates was often quite small, measuring only one or two enterprises in a given province; many different occupations were not covered by Spanish government records, especially professionals and businesspeople; much of workers' compensation was informal (especially for agricultural workers) ${ }_{i}^{67}$ agricultural workers were not included under the same surveys as industrial workers; and there was no practicable way of distinguishing among different classes of agricultural worker, such as between yeomen and hired farmhands. Considering these sources of random and systematic error, it seemed more plausible and fairer to an important control variable to employ broad income categories in the analysis. In particular, there were important differences between rural day-labourers and yeomen farmers in political preference. The latter were often excluded from Spanish left-wing coalitions, even where, as in Cantabria, they formed a large proportion of the rural poor ${ }^{68}$ Therefore, it

\footnotetext{
64. Collier and Hoeffler 2004

65. Ministerio de Trabajo y Previsión 1931

66. Bringas Gutiérrez 2000. Montes

67. Ministerio de Trabajo y Previsión 1931; Malaquer de Montes and Llonch 2005, 1205

68. Malefakis 1970, 112-121.
} 
seems wiser to employ a measure that distinguishes between these groups. In any event, when included as a regressor instead of occupational categories, income had no discernable relationship to the likelihood of desertion. ${ }^{69}$

Date of enlistment and age were straightforwardly coded from the soldiers' files. I included a square term for each, because there is a plausible non-linearity. In the Spanish Civil War, the very young — especially those under 21—and the old were thought to desert more often than those in their mid-20s. The young were thought to be fearful and vulnerable, the old to be too committed to their families. There was a greater cultural presumption that those in their mid-20s would serve. ${ }^{70}$ As for date of enlistment, I included a square term because two effects may be present: an early date of joining may indicate greater commitment, but a late date potentially subjects the soldier less to exhaustion and the burdens of war. It is possible, therefore, that date of enlistment has an inverted-U relationship with desertion rates. Marital status was also taken directly from soldiers' files. I included widowers under the category of married, because this variable is intended to capture soldiers' attachments at home, and widowers would have attachments to children and in-laws.

\begin{tabular}{|c|c|c|c|c|}
\hline \multirow[b]{2}{*}{ Categorical variables } & \multicolumn{2}{|c|}{ Analyzed sample } & \multicolumn{2}{|c|}{ Whole sample } \\
\hline & Frequency & Percent & Frequency & Percent \\
\hline $\begin{array}{l}\text { Non-deserters } \\
\text { Deserters }\end{array}$ & $\begin{array}{l}838 \\
416\end{array}$ & $\begin{array}{l}66.83 \\
33.17 \\
\end{array}$ & $\begin{array}{l}1305 \\
1313 \\
\end{array}$ & $\begin{array}{l}49.85 \\
50.15\end{array}$ \\
\hline $\begin{array}{l}\text { Conscripts } \\
\text { Volunteers }\end{array}$ & $\begin{array}{l}856 \\
398\end{array}$ & $\begin{array}{l}68.26 \\
31.74\end{array}$ & $\begin{array}{c}1200 \\
552\end{array}$ & $\begin{array}{c}68.49 \\
31.51\end{array}$ \\
\hline $\begin{array}{l}\text { Unaffiliated to left-wing organization } \\
\text { Affiliated to left-wing organization }\end{array}$ & $\begin{array}{l}345 \\
909\end{array}$ & $\begin{array}{r}27.51 \\
72.49 \\
\end{array}$ & $\begin{array}{l}443 \\
1221\end{array}$ & $\begin{array}{l}26.62 \\
73.38 \\
\end{array}$ \\
\hline $\begin{array}{l}\text { Single } \\
\text { Married }\end{array}$ & $\begin{array}{l}862 \\
392\end{array}$ & $\begin{array}{l}68.74 \\
31.26\end{array}$ & $\begin{array}{c}1450 \\
617\end{array}$ & $\begin{array}{l}70.15 \\
29.85\end{array}$ \\
\hline $\begin{array}{l}\text { Occupation: } \\
\text { Unskilled/day-labourer } \\
\text { Yeoman farmer } \\
\text { Mining/industrial } \\
\text { Services } \\
\text { Student } \\
\text { Commercial/professional }\end{array}$ & $\begin{array}{c}287 \\
421 \\
332 \\
174 \\
13 \\
27\end{array}$ & $\begin{array}{c}22.89 \\
33.57 \\
26.48 \\
13.88 \\
1.04 \\
2.15\end{array}$ & $\begin{array}{c}420 \\
799 \\
506 \\
279 \\
33 \\
58\end{array}$ & $\begin{array}{c}20.04 \\
38.14 \\
24.15 \\
13.32 \\
1.58 \\
2.77\end{array}$ \\
\hline $\begin{array}{l}\text { Home county: } \\
\text { Área de Santander } \\
\text { Asón-Ramales } \\
\text { Cabuérniga-Tudanca } \\
\text { Castro Urdiales } \\
\text { Costa Occidental } \\
\text { Laredo } \\
\text { Liébana } \\
\text { Pas-Castañeda } \\
\text { Reinosa-Campoo } \\
\text { Santoña-Miera } \\
\text { Torrelavega-Besaya } \\
\text { Other provinces }\end{array}$ & $\begin{array}{c}354 \\
60 \\
55 \\
41 \\
96 \\
48 \\
48 \\
100 \\
138 \\
142 \\
172\end{array}$ & $\begin{array}{c}28.23 \\
4.78 \\
4.39 \\
3.27 \\
7.66 \\
3.83 \\
3.83 \\
7.97 \\
11.00 \\
11.32 \\
13.72\end{array}$ & $\begin{array}{c}488 \\
104 \\
85 \\
66 \\
128 \\
82 \\
95 \\
159 \\
220 \\
286 \\
259 \\
174\end{array}$ & $\begin{array}{c}22.74 \\
4.85 \\
3.96 \\
3.08 \\
5.96 \\
3.82 \\
4.43 \\
7.41 \\
10.25 \\
13.33 \\
12.07 \\
8.12\end{array}$ \\
\hline Continuous Variables & $\begin{array}{l}\text { Mean } \\
\text { (SD) }\end{array}$ & $\begin{array}{l}\text { Minimum } \\
\text { Maximum }\end{array}$ & $\begin{array}{l}\text { Mean } \\
\text { (SD) }\end{array}$ & $\begin{array}{l}\text { Minimum } \\
\text { Maximum }\end{array}$ \\
\hline Age & $\begin{array}{l}25.89 \\
(5.42) \\
\end{array}$ & $\begin{array}{l}16 \\
62 \\
\end{array}$ & $\begin{array}{l}25.75 \\
(5.41)\end{array}$ & $\begin{array}{l}16 \\
62 \\
\end{array}$ \\
\hline Date of enlistment (days since 17 July 1936) & $\begin{array}{c}195 \\
(81.07)\end{array}$ & $\begin{array}{c}1 \\
384\end{array}$ & $\begin{array}{c}188 \\
(84.46)\end{array}$ & $\begin{array}{c}1 \\
391\end{array}$ \\
\hline
\end{tabular}

69. In addition, since my data cover only the period January-August 1937, there was no way of testing the effect of the harvest on the likelihood of desertion. Bearman 1991; Collier and Hoeffler 2004. This is unfortunate considering the prevalence of agricultural workers in my sample.

70. Corral 2007, 162-163. 


\begin{tabular}{|c|c|c|}
\hline & $\begin{array}{l}\text { Mean } \\
\text { (SD) }\end{array}$ & $\begin{array}{l}\text { Minimum } \\
\text { Maximum }\end{array}$ \\
\hline Altitude (metres above sea level) & $\begin{array}{c}237 \\
(280.82)\end{array}$ & $\begin{array}{c}5 \\
957\end{array}$ \\
\hline $\begin{array}{l}\text { Steepness index }=(\text { proportion of municipality's territory } 30-50 \% \\
\text { in slope } * .3)+(\text { proportion }>50 \% * .5)\end{array}$ & $\begin{array}{l}.0688 \\
(.084)\end{array}$ & $\begin{array}{c}0 \\
.326\end{array}$ \\
\hline Violence (deaths per 10,000 population as of 1930 ) & $\begin{array}{l}.170 \\
(.218)\end{array}$ & $\begin{array}{c}0 \\
1.3\end{array}$ \\
\hline Literacy rate (proportion) & $\begin{array}{c}.710 \\
(.0573) \\
\end{array}$ & .467 \\
\hline Right-wing vote share (proportion) & $\begin{array}{l}.670 \\
(.149)\end{array}$ & $\begin{array}{l}.302 \\
.950\end{array}$ \\
\hline
\end{tabular}

Summary statistics for each of these variables are given in Tables 1 and 2. Table 1 gives summary statistics of individual-level data, both for the sample of soldiers that is included in the statistical models and for the full sample before geographic limits and missing data delete cases. It also reports the eleven counties of Santander province, which aggregated its 102 municipalities, to show the basic geographic distribution of soldiers. Table 2 gives descriptives for the hometown-level variables, measured at the level of the 102 municipalities. One municipality had only six soldiers sampled, and they dropped out due to missing data, leaving 101.

Of the 2618 soldiers in the sample, over half are deleted from the eventual logit analysis, reducing the dataset to 1254 . Two further municipalities, with 43 soldiers, leave the analyses that include the steepness index, because it is not available for all municipalities. This large loss of cases is as a consequence mainly of missing data, but also because of the geographical limitation I placed on the dataset. Because of this large missing data problem, there is some concern about systematically missing data. As it is possible to see from Table 1, missing data has a large effect on the outcome variable, desertion rate. Deserters are much more likely to have missing data than non-deserters. Many deserters' military cards, especially before January 1937, are blank apart from their name, battalion number, and a report of their desertion; this indicates that the cards may have been created after the fact, as placeholders in a file-keeping system rather than as a substantive data-gathering operation. More substantively, this raises the concern that deserters about whom little is known are systematically different from deserters about whom much is known. It is obviously very difficult to determine this after the fact, but in any event the data must be interpreted with this possibility in mind: this paper can tell us about soldiers the army had records on, but not others. Thus, for example, it can say very little about soldiers who deserted prior to January 1937. Otherwise, yeomen farmers are under-represented; unskilled workers, day labourers, industrial workers and those from the capital region are over-represented. This indicates an urban bias in the eventual sample: more is apparently known about urban soldiers than about rural soldiers. This is consistent with my overall approach to the core and periphery, but it represents something of a selection bias. 


\section{Results}

\begin{tabular}{|c|c|c|c|c|}
\hline Dependent variable: $0=$ did not desert; $1=$ deserted & $\begin{array}{c}\text { Model } 1 \\
\text { Estimate } \\
\text { (s.e.) }\end{array}$ & $\begin{array}{c}\text { Model } 2 \\
\text { Estimate } \\
\text { (s.e.) }\end{array}$ & $\begin{array}{c}\text { Model } 3 \\
\text { Estimate } \\
\text { (s.e.) }\end{array}$ & $\begin{array}{c}\text { Model } 4 \\
\text { Estimate } \\
\text { (s.e.) }\end{array}$ \\
\hline Volunteer & $\begin{array}{c}-1.529 * * * \\
(.258) \\
\end{array}$ & $\begin{array}{c}-1.727 * * * \\
(.271) \\
\end{array}$ & $\begin{array}{c}-1.813 * * * \\
(.255) \\
\end{array}$ & $\begin{array}{c}-1.826 * * * \\
(.256) \\
\end{array}$ \\
\hline Left-wing affiliation & $\begin{array}{l}-.870 * * * \\
(.165)\end{array}$ & $\begin{array}{c}-.803^{* * *} \\
(.167)\end{array}$ & $\begin{array}{l}-.775 * * * \\
(.157)\end{array}$ & $\begin{array}{c}-.775 * * * \\
(.157)\end{array}$ \\
\hline Married & $\begin{array}{l}-.121 \\
(.190) \\
\end{array}$ & $\begin{array}{l}-.113 \\
(.193) \\
\end{array}$ & & \\
\hline Age & $\begin{array}{l}.330 * \\
(.165) \\
\end{array}$ & $\begin{array}{l}.241 \\
(.161) \\
\end{array}$ & & \\
\hline Age squared & $\begin{array}{l}-.00579 \\
(.00310)\end{array}$ & $\begin{array}{l}-.00416 \\
(.00302)\end{array}$ & & \\
\hline Date of enlistment & $\begin{array}{l}.0247 * * \\
(.00621) \\
\end{array}$ & $\begin{array}{l}.0249 * * * \\
(.00632) \\
\end{array}$ & $\begin{array}{l}.0283^{* * * *} \\
(.00617)\end{array}$ & $\begin{array}{l}.0283^{* * *} \\
(.00619) \\
\end{array}$ \\
\hline Date of enlistment squared & $\begin{array}{c}-.000054 * * \\
(.0000156) \\
\end{array}$ & $\begin{array}{c}-.0000564^{* * *} \\
(.0000158) \\
\end{array}$ & \begin{tabular}{|c|}
$-.0000665^{* * *}$ \\
$(.0000152)$ \\
\end{tabular} & $\begin{array}{l}-.0000666 \\
(.0000153) \\
\end{array}$ \\
\hline Occupation: Yeoman & $\begin{array}{l}.180 \\
(.210) \\
\end{array}$ & $\begin{array}{c}.183 \\
. .216)\end{array}$ & & \\
\hline Occupation: Mining or industrial & $\begin{array}{l}.488^{*} \\
(.224) \\
\end{array}$ & $\begin{array}{l}.562 * \\
(.230) \\
\end{array}$ & & \\
\hline Occupation: Services & $\begin{array}{l}.0436 \\
(.271) \\
\end{array}$ & \begin{tabular}{|l}
.143 \\
$(.279)$ \\
\end{tabular} & & \\
\hline Occupation: Student & $\begin{array}{l}1.602 * \\
(.698)\end{array}$ & $\begin{array}{c}1.677^{* *} \\
(.709)\end{array}$ & & \\
\hline Occupation: Commercial or professional & $\begin{array}{l}.0944 \\
(.524) \\
\end{array}$ & $\begin{array}{l}.249 \\
(.522) \\
\end{array}$ & & \\
\hline Hometown altitude & $\begin{array}{l}.000592 \\
(.000315) \\
\end{array}$ & & & \\
\hline Hometown steepness a & & $\begin{array}{c}3.698 * * \\
(1.081) \\
\end{array}$ & $\begin{array}{c}3.345 * * \\
(1.026) \\
\end{array}$ & $\begin{array}{l}2.705^{*} \\
(1.342)\end{array}$ \\
\hline Hometown literacy rate & $\begin{array}{c}-.668 \\
(1.745) \\
\end{array}$ & $\begin{array}{l}1.238 \\
(1.681) \\
\end{array}$ & & \\
\hline Hometown violence & $\begin{array}{l}.0672 \\
(.395) \\
\end{array}$ & $\begin{array}{l}-.0498 \\
(.378) \\
\end{array}$ & & \\
\hline Hometown right-wing vote share ${ }^{a}$ & $\begin{array}{l}.0255^{* * *} \\
(.00619) \\
\end{array}$ & $\begin{array}{l}.0207 * * \\
(.00636) \\
\end{array}$ & $\begin{array}{c}.0199 * * \\
(.00603) \\
\end{array}$ & $\begin{array}{l}.0201^{* *} \\
(.00596) \\
\end{array}$ \\
\hline Right-wing vote * steepness a & & & & $\begin{array}{l}.0508 \\
(.0703) \\
\end{array}$ \\
\hline Constant & $\begin{array}{c}-9.767 * * * \\
(2.451) \\
\end{array}$ & $\begin{array}{c}-9.982 * * * \\
(2.384) \\
\end{array}$ & $\begin{array}{c}-5.763 * * * \\
(.693) \\
\end{array}$ & $\begin{array}{c}-2.542 * * * \\
(.602) \\
\end{array}$ \\
\hline Variance in constants & $\begin{array}{l}.309 * \\
(.172) \\
\end{array}$ & $\begin{array}{l}.186 \\
(.300) \\
\end{array}$ & $\begin{array}{l}.224 \\
(.229) \\
\end{array}$ & $\begin{array}{l}.201 \\
(.263) \\
\end{array}$ \\
\hline Log likelihood & -624.326 & -596.569 & -603.882 & -.603 .623 \\
\hline BIC statistic & 1377.065 & 1320.924 & 1264.558 & 1271.14 \\
\hline $\mathrm{N}$ of individuals & 1254 & 1211 & 1211 & 1211 \\
\hline $\mathrm{N}$ of hometowns & 101 & 99 & 99 & 99 \\
\hline
\end{tabular}

$* p<.05 ; * * p<.01 ; * * * p<.001$

a In Model 4 , right-wing vote share and steepness are centered at the grand mean. 
I first ran two multilevel logit models, corresponding to altitude and steepness. Results are in Table 3. In Model 1, the relationship between altitude and desertion is positively signed, as expected, but this relationship falls just short of statistical significance at the .05 level $(p>.06)$. In Model 2, however, rough terrain has a much stronger, and statistically significant, association with desertion. Despite the fact that 43 cases and two municipalities drop out of the data set because of unavailable data on steepness, Model 2 has a lower Bayesian Information Criterion (BIC) statistic, indicating a better fit to the data. The result for steepness is also substantively important. Based on Model 2 's estimates, I predicted probabilities of desertion for a typical soldier-mean age and date of enlistment, from a hometown with mean literacy, violence, and right-wing vote share, and modal values on the other variables. This hypothetical soldier is thus 26 years old, joined 195 days after the start of fighting, and is an unmarried, conscripted yeoman farmer who is affiliated with a Popular Front organization, from a hometown with .17 deaths per 10,000 pre-war population, a literacy rate of $71 \%$, and $67 \%$ support for right-wing parties. Predicted probabilities of desertion at different levels of steepness are then given in Figure 4. As it indicates, a soldier from the steepest municipality had, on average, 3.15 times the likelihood of desertion as a soldier from the flattest.

\section{Figure 4. Predicted Probabilities of Desertion According to Home Municipality Steepness Index, for a Typical Soldier, with 95\% Confidence Interval}

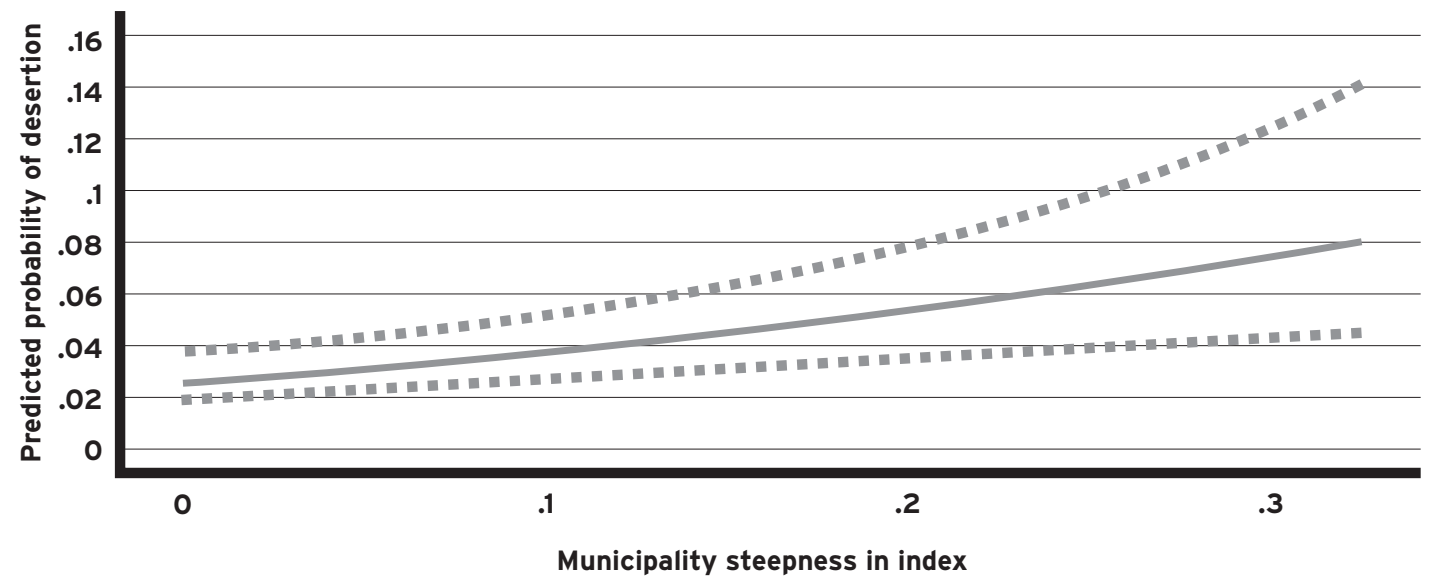

Based on estimates in Model 2

Thus it is the roughness of the terrain, rather than altitude, that drives the association between geography and desertion rates. The result for altitude is substantially weaker. As I argue above, steepness is a better indicator of the opportunity to hide, since it captures the ruggedness of terrain rather than its elevation. Mountains should have a comparative advantage over plateaus in the opportunity to hide, as should rough coastal terrain over coastal plains.

We can better characterize the relationship between terrain and desertion through a visual representation. Reporting the raw percentage of deserters in my da- 
taset across each steepness decile (for example) would not be useful in giving raw rates of desertion, because my sampling method, by design, inflates the proportion of deserters. Instead, in order to generate as close to true rates of desertion as possible, given my sampling method, I ran a logit model of desertion against deciles of the steepness index alone, with no other covariates. I then adjusted its estimates of the desertion rate according to King and Zeng's "prior correction" method for adjusting the constant term to account for the sampling technique. ${ }^{71}$ This gives an estimate of percentage of deserters at each decile, adjusted to reflect the fact that the true proportion of deserters is much lower in the population than in my sample. The results are given in Figure 5. They indicate that the desertion rate increases considerably from the lowest to the highest decile, but that variation in desertion rate across the flattest half of the municipalities is better characterized as trendless fluctuation. Terrain appears to have its effect at the upper reaches of steepness, rather than at the lower end.

\section{Figure 5. Desertion rates by steepness decile (with standard error of estimate)}

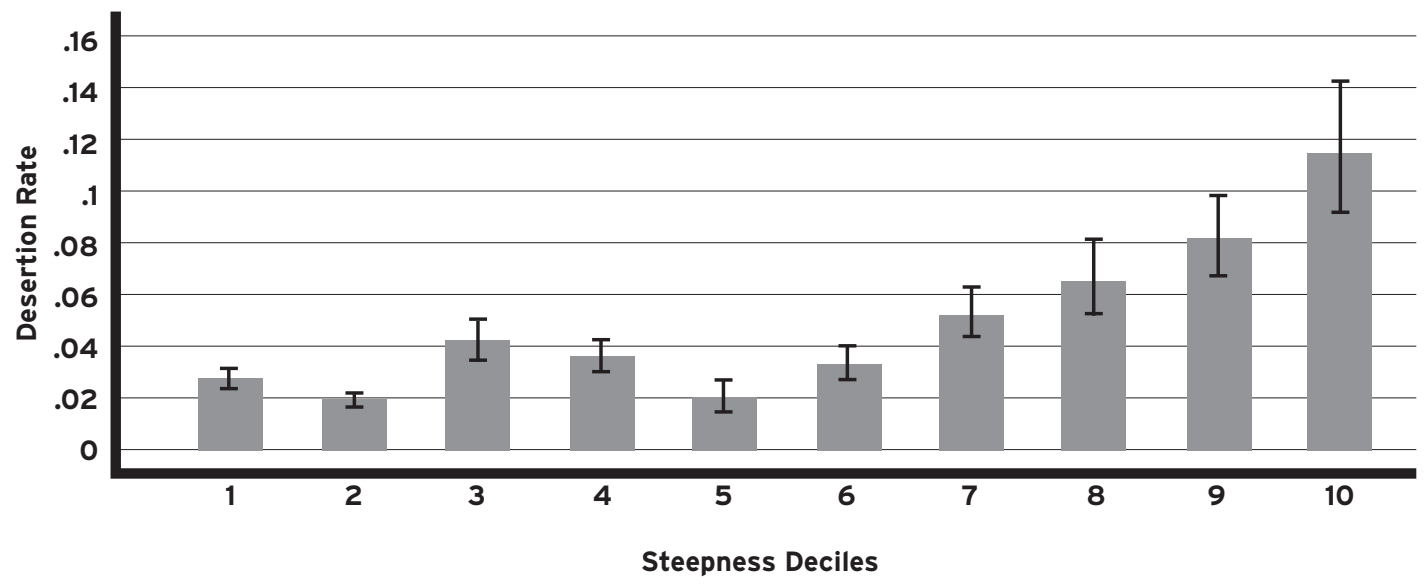

Based on estimates in Model 2

Local right-wing vote share had a robust, positively signed association with desertion. This indicates that, in general, the stronger the local right wing, the likelier desertion was among soldiers from a given municipality. However, it is not immediately obvious how to interpret this result. It might be taken as an ecological indicator, suggesting that individual soldiers from right-wing locations were more likely to hold right-wing attitudes themselves. The association with desertion rates would then be explained by the stronger motivation of the soldiers in question not to fight for the Left. However, because of the logical difficulties of ecological analysis, other possibilities exist. Right-wing communities may have provided help to deserters of any political stripe, and may have been places where the left had a weak local organizational presence. Both factors suggest that such communities were places where

71. King and Zeng 2001 
soldiers would have a better chance at deserting without being caught. Adjudicating this relationship appears to be an important area for future research.

Local violence, included for investigative purposes rather than for hypothesis testing, had no apparent relationship with the likelihood of desertion. This is unsurprising since, as noted above, there is a plausible case that violence can indicate either lack of control or efforts to reassert that control. Similarly, literacy rates did not have any clear association with desertion rates. This suggests that even if local development patterns gave individuals different economic interests in fighting, this did not translate into a decision to desert or not to desert.

As for the control variables, voluntarism versus conscription was, of course, substantively important across all models, as was membership in a popular-front organization. The date of enlistment was likewise important: later recruits were overall more likely to desert than earlier recruits, but the negative sign on the square term indicates a downward-trending curvilinear relationship. That is, as time wears on further, later recruits have a lower likelihood of desertion. Interestingly, the demographic variables of marital status and age had no clear relationship with desertion. There is also very little clear association between occupational categories and desertion, with the exception of frequently-deserting students. This finding fits an interpretation where those with better economic opportunities outside the armed group desert more often: students (especially military-age students, who would generally be in college or university) came from elite families. But the lack of other consistent relationships with occupational categories-especially yeomen farmers, who were clearly better-off than day-labourers-suggests that this is not a robust conclusion. However, the lack of an apparent association could be an artifact of the limitations of my occupational categorization scheme. It is unclear that the occupational codings add much information for the investment of degrees of freedom: the BIC statistic for a model without the occupations (not shown) is lower, 1297.051 as compared to 1320.924 for Model 2. In fact, a stripped-down model, removing the apparently non-influential demographic indicators of marital status, age, and occupation, and the apparently unimportant hometown conditions of violence and literacy rates, performs rather better given the investment of degrees of freedom (Model 3): the BIC statistic clearly declines, from 1320.924 in the best-fitting saturated model to 1264.558 .

Does rough terrain facilitate desertion in all municipalities, or only in some political settings? This question essentially addresses the uniformity of the relationship between terrain and desertion, allowing us to characterize the result more fully. The more general the result, the more universal the importance of terrain; it would suggest that terrain is not just something that affects some municipalities' desertion rates and not others. In Model 4 I explore an interaction effect, using the strippeddown Model 3 as a baseline for clarity's sake. This model follows Enders and Tofighi's advice $^{72}$ to handle interaction effects among second-level variables by centering them

72. Enders and Tofighi 2007. 
at the grand mean. The interaction term is not statistically significant. This indicates that the relationship between terrain and desertion is relatively general; it offers opportunities for anyone to desert, regardless of local political conditions.

Motivation differences need not be limited to the left-right master cleavage. Histories and ethnographies of mountain peoples, notably Scott's recent important contribution, frequently indicate a strong preference for autonomy from lowland political authority. ${ }^{73}$ One might then argue that such a systematic pattern is not controlled for by my data, and could account for the observed relationship between steepness and desertion. However, a stronger preference for not being subject to an outsider's authority should also translate into a resistance against joining up in the first place. Soldiers with that preference should thus be more likely than other soldiers to be conscripts. The voluntarism variable should therefore control for much of the effect of a difference in values. In addition, one would expect a cultural preference for autonomy from the centre to be associated with a broader disengagement from the centre's politics. I therefore estimated a separate model, not reported here, controlling for turnout to vote in the February 1936 elections as a measure of political alienation; there is no apparent relationship to desertion rates.

\section{Qualitative evidence from Santander}

The statistical analysis above is strongly suggestive of an association between difficult terrain and high desertion rates. Does this association occur for the suggested reason-because deserters from towns with rough terrain, and their families, find it relatively easy to hide? There is suggestive anecdotal evidence in this regard. In this section I draw heavily on the work of Fernando Obregón Goyarrola, whose interviews in Cantabria have led to multiple volumes of local history of the war.

Deserters did worry about capture, attempting to develop a good knowledge of where army posts and patrols were located in order to avoid being caught. ${ }^{74}$ This suggests the importance of whatever could help a soldier hide. The hills, of course, could help them hide, and the advantages of the hills loomed large in the calculations of deserters. One civilian witness from a valley distinguishes between "arriba" (above) and "abajo" (below, where he lived) in describing the importance of the hills: "Those from [the village of] Esles up above... did not want to go the militia ...Around here, below, there wasn't anyone who was hiding out." The mountains of the Peña Herrera massif, near Esles, served as a refuge for dozens, and, according to Obregón, "it was said that the militiamen never came up looking for them." ${ }^{75}$ Those who were actually from hilly areas had particular advantages. A good knowledge of the terrain could assist with

73. Scott 2009 .

74. Obregón Goyarrola 2005, 90; Obregón Goyarrola 2007, 131-132; García Guinea 2005.

75. Obregón Goyarrola 2005, 90, 157 
hiding. The Pasiegos, a group of nomadic pastoralists in the Pas area, ${ }^{76}$ typically made their way in itinerant fashion among a network of cabins in the hills. When Pasiego soldiers deserted-which was often, according to a June 1937 letter from the commander of the $2^{\text {nd }}$ Division ${ }^{77}$ - they tended to hide in those very cabins. ${ }^{78}$ In contrast, those who did the searching were frequently lowlanders, according to one witness: "If they caught you they shot you, but they [the Republican military authorities] did not know [the hills]." ${ }^{79}$ Noted the commander of the $2^{\text {nd }}$ Division, the Pas area "even in normal times is difficult to control." ${ }^{80}$

In addition, local contacts in the hills were of vital importance. Where deserters did not know the terrain, they could attempt to arrange a local guide, for a fee. ${ }^{81}$ Help from family and friends could be quite important for deserters, and they could make more credible commitments to help. For example, in the Pas region, one witness remembers keeping his brother in a hay loft for several days early on in the Spanish Civil War. Another remembers that her fiancé was kept hidden in a sort of sepulchre in his mother's house for nine months, his mother advising him whenever a carindicating a patrol-was coming. ${ }^{82}$ Neighbours also helped: "if anyone came from Santander to look for us, our neighbours warned us. We lived this way almost a year, until [the Nationalists] took Santander." ${ }^{\prime 3}$

Families were also very important because, as elsewhere, family members were punished for desertion. It was standard bureaucratic procedure in Santander province to initiate a local investigation and attempt to apprehend family members. The standard order to a local municipal government was to detain the deserter in question, but if he could not be detained within 48 hours, the government was directed to seize his family and goods. ${ }^{84}$ This applied both to deserters and to defectors. In a typical example, when a soldier in Battalion 118 deserted, the head of the Information Section of the General Staff wrote the Popular Front committee of his town of residence, Torrelavega, to request that an investigation take place to determine if his family or friends was sheltering him or if one of them might have encouraged him to defect to the enemy. ${ }^{85}$ If a soldier could anticipate that his family was likely to suffer from his defection, therefore, he might be less likely to defect. Deserters' families were apparently able to escape punishment more easily if they lived in mountain districts. Whole families in Reinosa, a mid-size town in southern Santander province nestled in a valley, took to the nearby hills for safety at the outset of the war. ${ }^{86}$ Civilians also took to the hills to flee in the Pas district, where they were aided by the thick fogs that were characteristic of hill country. ${ }^{87}$

\footnotetext{
76. Freeman 1979.

77. Jefe, 2a División, to Sr. Jefe del C. de E. de Santander, Ontaneda, 23 June 1937. AGMAV, DR, armario 63, legajo 855, carpeta 1, documento 1, page 3.

78. Obregón Goyarrola 2009, 125; Obregón Goyarrola 2005, 90.

79. Obregón Goyarrola 2005, 90; bracketed notes are Obregón's.

80. Jefe, 2a División, to Sr. Jefe del C. de E. de Santander, Ontaneda, 23 June 1937. AGMAV, DR, armario 63, legajo 855, carpeta 1, documento 1, page 3.

81. Obregón Goyarrola 2007, 176.

82. Obregón Goyarrola 2009, 125, 192

83. Obregón Goyarrola 2005, 90; bracketed notes are Obregón's.

For example, Jefe de Investigación, II Cuerpo, Ejército del Norte to Alcalde-Presidente del Consejo Municipal, Los Tojos, Santander, 9 August 1937. CDMH, PS Santander L, caja 412, carpeta 18, page 25.

85. Jefe, $2^{a}$ Sección, Estado Mayor, Cuerpo de Ejército de Santander, to Frente Popular de las Izquierdas, Torrelavega, Santander, 22 June 1937. CDMH, PS Santander L, caja 406, carpeta 5, page 57.

86. García Guinea 2005, 17

87. Obregón Goyarrola 2009, 132-134.
} 
There is evidence, in addition, that mountain districts had distinctive attitudes to politics as a consequence of their isolation. As noted, the left had very little presence in mountain districts, where industrialization and the labour movement had not penetrated very far. Right-wing villages occasionally provided refuge for hidden deserters, and deserters sometimes conceived of physical space in political, left-right terms. One deserter from Lloreda remembers: "We were hidden, there were many who were hidden, Lloreda was a very right-wing village." ${ }^{88}$ In other places, the right wing itself had little presence either; some districts found themselves quite isolated from politics. In Liébana, among the most mountainous regions of the province, a common expression captures removal from the war and its agendas because of isolation: "The war happened on the highway", and there was extremely little highway access in Liébana at the time. ${ }^{89}$ While Liébana was certainly right-wing politically, this was, it seems, more a default option than strong mobilization by the right: before the war, Catholic agricultural syndicates, a key locus of right-wing organizing, had as little presence as left-wing labour unions..$^{90}$ The hills could just be isolated, rather than strongly motivated for the other side. Indeed, right-wing sentiment, though prevailing over left-wing attitudes in the mountains, was not determinative of the role of the mountains in civil war. An interesting piece of evidence comes from Liébana as well. This was both a district of very high desertion from the Loyalist side and a key locus of eighteen years of anti-Franco guerrilla fighting after the war. ${ }^{91}$ This was not just guerrilleros from other districts taking advantage of the hill country: in fact, Lebaniego soldiers themselves staffed the guerrilla force in this district, drawing once again on families and friends and their local knowledge to evade capture. While their activity generated local resentment for the repression that it produced, and while places that identified as right-wing often denied the guerrilleros aid, the fact that the guerrilleros got assistance from villages at all says something telling about hills. They help people hide, no matter what "side" they are hiding from. It is their association with opportunities and the evasion of capture, rather than their association with the left-right master cleavage of the war, that produces hills' association with desertion.

\section{Conclusion: Location and Control in Civil Wars}

This paper has established that an important source of variation in desertion rates is control of a soldier's hometown, and in particular terrain as a structural constraint on that control. This finding can potentially be replicated in other instances. There is one other systematic, large-N study of desertion that examines the impact of terrain. Giuffre attributes the high desertion rates of upland North Carolina soldiers to their disconnection from the slave economy, and thus to their lack of motivation to fight to defend that system..$^{92}$ This is certainly a plausible account, but the more fre-

88. Obregón Goyarrola 2005, 90

89. Obregón Goyarrola 2007, 23.

90. Ibid., 38.

91. Ibid., 334-335, 340-349.

92. Giuffre 1997 
quently the finding is replicated elsewhere, the more we would be forced to abstract from particular motivation stories and shift instead to opportunity structures.

Beyond replication, the finding suggests other testable hypotheses. We can test whether the finding holds in broad, cross-national terms. It is often difficult to find out the geographic composition of a military, but the use of forces recruited locally to a conflict zone is better-documented, and I am therefore currently gathering data on the government use of local forces and their desertion rates in civil wars in the 1990s. In addition, much effort has recently been deployed at gathering data on geographic features of conflict zones on a broad basis..$^{93}$ Thus we can test the hypothesis that if local forces are employed in a rough-terrain conflict zone, they should be more likely to desert than local forces in easier ground. In addition, scholars are beginning to investigate the sources of the fragmentation of armed groups in civil wars; in particular, Fjelde and Nilsson suggest that fragmentation comes as a result of structural opportunities for a sub-faction to break away. ${ }^{94}$ Terrain may be one source of such opportunities, though Fjelde and Nilsson do not investigate it. We can expect, however, higher rates of fragmentation in civil wars fought in more difficult terrain.

The paper's central finding suggests some important theoretical openings. It proposes a new view of control over the rearguard. Whereas Kalyvas argues that there is strong control in zones that are uncontested by opponents, ${ }^{95}$ this paper suggests that this control may vary even in such zones, with important consequences for the war effort. Scholars such as Weinstein have also argued that patterns of control and governance of civilians well away from the fighting may vary in important ways. Weinstein focuses on characteristics of armed groups, particularly their initial resource endowments, to explain this variation: armed groups without strong economic endowments must negotiate a more cooperative relationship with a civilian population. Commitments made in a process of local negotiation are thus more credible. ${ }^{96}$ This paper goes beyond Weinstein to identify terrain as a novel, structural source of control patterns. In turn, terrain may have important downstream effects on the process of negotiation between armed group and civilian community. If it is particularly expensive for an armed group to impose its control over a place, the armed group may be willing to make greater concessions in negotiating an alliance with the civilian community working there: for example, greater autonomy, lower taxation rates, or more favourable terms of service for that community's young men. Mountainous terrain thus may create a sharp tradeoff for the armed group's leadership: between the cost of imposing control and the cost of creating incoherent, chaotic organizational structures. ${ }^{97} \mathrm{In}$ turn, the fragmentation of armed groups may create difficulties in resolving conflicts in peripheral zones over the long term, because of the proliferation of veto players. ${ }^{98}$

\footnotetext{
93. Buhaug, Gates, and Lujala 2009; Raleigh et al. 2010

94. Fjelde and Nilsson 2011.

95. Kalyvas 2006.

96. Weinstein 2007

97. Cunningham, Gleditsch, and Salehyan 2009.

98. Cunningham 2006
} 
The paper suggests a further sharp tradeoff around local knowledge. Local knowledge is a precious military asset, especially in counterinsurgency, ${ }^{99}$ but soldiers who have good local knowledge can use it to desert as well as to fight. I have made the point that deserters with good knowledge of mountainous terrain have an advantage over members of the armed group tasked with finding them, but the point may be more general: if a soldier knows where the enemy is hiding, he knows where he may hide. If he knows which civilians shelter the adversary, he knows where he may find shelter. Do armed groups consciously limit their soldiers' autonomy and choose not to recruit soldiers with local knowledge in order to guarantee their reliability? There an analogous hint in international conflict that states limit their armed forces' capabilities if they fear the coup potential of such capabilities. ${ }^{100}$ Future research can assess the degree to which that decision really exists, and the circumstances in which different armed groups are likely to play the tradeoff differently.

There may be reasons why some armed groups have better access to information than others. In particular, small armed groups may be able to draw on dense social networks and have better information about their soldiers' motivations. ${ }^{101}$ This suggests, further, that armed groups whose ambitions are limited in geographic and population scope may have a comparative advantage in reliability. As well, information may be constructed in the course of conflict. I argue elsewhere that when actors such as a military elite regard a particular marker-such as communal identity-as a good indicator of a soldier's reliability, it creates a kind of self-fulfilling prophecy. Out-groups, under suspicion, have little reason not to switch sides if possible, while in-groups have all the more reason to fear the outcome of defeat. In a sense, then, motivations may come to be "revealed" endogenously. ${ }^{102}$ This paper has not carried on with this point, focusing instead on static moments without such pervasive group markers, but studying the construction of markers of loyalty can add a layer of richness to theorizing.

It is a trope of the literature to focus on the revolt of the periphery against the centre, with the insurgency employing guerrilla tactics, swimming in the sea of the people and enjoying home-field advantage. ${ }^{103}$ This paper suggests that, sometimes, peripheries play other roles: peripheral to the war itself. The mountain villages of Santander province found themselves caught between two major political entities based in large cities and fighting it out for control of the state centre. Though most villages certainly had a preference for the right over the left, this preference does not appear strongly associated with a hometown's propensity for desertion. This suggests that a peripheral position can help people avoid the war entirely, not just enable them to resist the government side. As new civil war projects compare the local geographic conditions of wars, therefore, they should be cognizant of this ability of peripheries to remove themselves from the war. If soldiers from the hills do not want to fight, they can perhaps go home again.

99. Kilcullen 2010.

100. Biddle and Zirkle 1996

101. Weinstein 2007.

102. McLauchlin 2010

103. Arreguín-Toft 2006; Kilcullen 2010. 


\section{References}

Archives

Centro Documental de la Memoria Histórica, Salamanca (CDMH)

Archivo General Militar, Ávila (AGMAV)

Alpert, Michael. 1989. El ejército republicano en la Guerra civil. 2nd ed. Madrid: Siglo XXI.

Arjona, Ana M., and Stathis N. Kalyvas. 2006. Preliminary Results of a Survey of Demobilized Combatants in Colombia. New Haven: Yale University.

Arreguín-Toft, Ivan. 2006. How the Weak Win Wars: A Theory of Asymmetric Conflict. Cambridge: Cambridge University Press.

Balcells, Laia. 2010. Rivalry and Revenge: Violence Against Civilians in Conventional Civil Wars. International Studies Quarterly, 54 (2): 291-313.

Bearman, Peter S. 1991. Desertion As Localism: Army Unit Solidarity and Group Norms in the U.S. Civil War. Social Forces, 70 (2): 321-342.

Beevor, Antony. 2006. The Battle for Spain: The Spanish Civil War, 1936-1939. London: Weidenfeld \& Nicolson.

Beevor, Antony. 1982. The Spanish Civil War. London: Cassell.

Biddle, Stephen D. 2004. Military Power: Explaining Victory and Defeat in Modern Battle. Princeton: Princeton University Press.

Biddle, Stephen, and Robert Zirkle. 1996. Technology, civil-military relations, and warfare in the developing world. Journal of Strategic Studies, 19: 171-212.

Bolloten, Burnett. 1991. The Spanish Civil War: Revolution and Counterrevolution. Chapel Hill: University of North Carolina Press.

Boulding, Kenneth E. 1962. Conflict and Defense: A General Theory. New York: Harper Torchbooks.

Bringas Gutiérrez, Miguel Ángel. 2000. La productividad de los factores en la agricultura española (1752-1935). Madrid: Banco de España - Servicio de Estudios.

Buhaug, Halvard, Scott Gates, and Päivi Lujala. 2009. Geography, Rebel Capability, and the Duration of Civil Conflict. Journal of Conflict Resolution, 53 (4): 544569.

Cardona, Gabriel. 2006. Historia militar de una guerra civil: estrategias y tácticas de la guerra de España. Barcelona: Flor del Viento Ediciones.

Carr, Raymond. 1977. The Spanish Tragedy: The civil war in perspective. London: Weidenfeld \& Nicolson.

Christia, Fotini. 2008. Following the Money: Muslim versus Muslim in Bosnia's Civil War. Comparative Politics, 40 (4): 461-480.

Cohen, Youssef, Brian R. Brown, and A.F.K. Organski. 1981. The Paradoxical Nature of State Making: The Violent Creation of Order. American Political Science Review, 75 (4): 901-910.

Collier, Paul, and Anke Hoeffler. 2004. Greed and Grievance in Civil War. Oxford Economic Papers, 56: 563-595.

Corral, Pedro. 2007. Desertores: la guerra civil que nadie quiere contar. Barcelona: Crítica.

Costa, Dora L., and Matthew E. Kahn. 2003. Cowards And Heroes: Group Loyalty In The American Civil War. Quarterly Journal of Economics, 118 (2): 519-548. 
Costa, Dora L., and Matthew E. Kahn. 2008. Heroes \& Cowards: the Social Face of War. Princeton University Press.

Costa, Dora L., and Matthew E. Kahn. 2004. Shame and Ostracism: Union Army Deserters Leave Home. National Bureau of Economic Research Working Paper Series, No. 10425.

Cunningham, David E. 2006. Veto Players and Civil War Duration. American Journal of Political Science, 50 (4): 875-892.

Cunningham, David E., Kristian Skrede Gleditsch, and Idean Salehyan. 2009. It Takes Two. Journal of Conflict Resolution, 53 (4): 570-597.

DeNardo, James. 1985. Power in Numbers: The Political Strategy of Protest and Rebellion. Princeton: Princeton University Press.

Dirección General del Instituto Geográfico, Catastral y de Estadística, Presidencia del Consejo de Ministros. 1930. Censo de la Población de España. Talleres del Instituto Geográfico y Catastral.

Enders, Craig K., and Davood Tofighi. 2007. Centering predictor variables in crosssectional multilevel models: A new look at an old issue. Psychological Methods, $12(2): 121-138$.

Enloe, Cynthia H. 1980. Ethnic Soldiers: State Security in Divided Societies. Athens, GA: University of Georgia Press.

Fairbanks, Charles H. Jr. 1995. The Postcommunist Wars. Journal of Democracy, 6 (4): 18-34.

Fjelde, Hanna, and Desiree Nilsson. 2011. Rebels Divided: Fragmentation of the Rebel Side in Civil Wars, 1975-2008. Presented at the International Studies Association Annual Convention, Montreal, March 16-19.

Freeman, Susan Tax. 1979. The Pasiegos: Spaniards in No Man's Land. Chicago: University of Chicago Press.

Gámir Ulibarri, Mariano. 1939. Guerra de España: 1936-1939. Paris: Estrella.

García Guinea, Luís. 2005. Diario de Guerra: un paréntesis de tres años (1936-1939). Palencia: Cultura \& Comunicación.

Gates, Scott. 2002. Recruitment and Allegiance: The Microfoundations of Rebellion. Journal of Conflict Resolution, 46 (1): 111-130.

Giuffre, Katherine A. 1997. First in Flight: Desertion as Politics in the North Carolina Confederate Army. Social Science History, 21 (2): 245-263.

Graham, Helen. 2002. The Spanish Republic at War 1936-1939. Cambridge: Cambridge University Press.

Gutiérrez Flores, Jesús. 2006. Guerra Civil en Cantabria y Pueblos de Castilla (19361939). Libros en Red.

Gutiérrez Lázaro, Cecilia, and Antonio Santoveña Setién. 2000. U.G.T. en Cantabria, 1888-1937. Santander: Universidad de Cantabria.

Herbst, Jeffrey. 2000. States and Power in Africa. Princeton: Princeton University Press.

Horowitz, Donald. 2000. Ethnic Groups in Conflict. 2nd ed. Berkeley and Los Angeles: University of California Press.

Humphreys, Macartan, and Jeremy M. Weinstein. 2004. What the Fighters Say: A Survey of Ex-Combatants in Sierra Leone - June-August 2003 Interim Report. New York: Columbia University.

Instituto Cántabro de Estadística. 2009. Relieve. Available from <http://www. icane.es/opencms/export/sites/default/Series_Estadisticas_Municipales/1._ Territorio_y_Medio_Ambiente/MU_1_1.xIs . 
Johnston, Patrick. 2008. The Geography of Insurgent Organization and its Consequences for Civil Wars: Evidence from Liberia and Sierra Leone. Security Studies, 17 (1): 107-137.

Kalyvas, Stathis N. 2008. Ethnic Defection in Civil War. Comparative Political Studies, 41 (8): 1043-1068.

Kalyvas, Stathis N. 2006. The Logic of Violence in Civil War. Cambridge: Cambridge University Press.

Kalyvas, Stathis N. 2003. The Ontology of 'Political Violence': Action and Identity in Civil Wars. Perspectives On Politics, 1 (3): 475-94.

Kalyvas, Stathis N., and Matthew Adam Kocher. 2007. How 'Free' is Free Riding in Civil Wars? Violence, Insurgency, and the Collective Action Problem. World Politics, 59 (2): 177-216.

Kaufmann, Chaim. 1996. Intervention in ethnic and ideological civil wars: Why one can be done and the other can't. Security Studies, 6: 62-101.

Kilcullen, David. 2010. Counterinsurgency. Oxford: Oxford University Press.

King, Gary, and Langche Zeng. 2001. Logistic Regression in Rare Events Data. Political Analysis, 9: 137-163.

Lilja, Jannie, and Lisa Hultman. 2011. Intraethnic Dominance and Control: Violence Against Co-Ethnics in the Early Sri Lankan Civil War. Security Studies, 20 (2): 171-197.

Linz, Juan J, and Jesús M de Miguel. 1977. Hacia un análisis regional de las elecciones de 1936 en España. Revista española de la opinión pública, 48: 27-68.

Lonn, Ella. 1928. Desertion During the Civil War. New York: Century.

Malaquer de Montes, Jordi, and Montserrat Llonch. 2005. Trabajo y relaciones laborales. In Albert Carreras and Xavier Tafunell (Eds). Estadísticas Históricas de España, Vol. 3. 2nd ed. Bilbao: Fundación BBVA.

Malefakis, Edward E. 1970. Agrarian Reform and Peasant Revolution in Spain: Origins of the Civil War. New Haven: Yale University Press.

Mann, Michael. 1986. The Sources of Social Power. 2 vols. Cambridge: Cambridge University Press.

Marshall, S.L.A. 1947. Men against fire: the problem of battle command. New York: William Morrow \& Co.

Martínez Bande, José. 1972. El Final del Frente Norte. Madrid: Editorial San Martín.

Martínez Bande, José. 1980. Nueve meses de guerra en el norte. 2nd ed. Madrid: Editorial San Martín.

McColl, Robert W. 1969. The Insurgent State: Territorial Bases of Revolution. Annals of the Association of American Geographers, 59 (4): 613-631.

McLauchlin, Theodore. 2010. Loyalty Strategies and Military Defection in Rebellion. Comparative Politics, 42 (3): 333-350.

Migdal, Joel S. 1988. Strong Societies and Weak States: State-Society Relations and State Capabilities in the Third World. Princeton: Princeton University Press.

Ministerio de Trabajo y Previsión, Dirección General de Trabajo. 1931. Estadística de Salarios y Jornadas de Trabajo, Referida al Período 1914-1930. Madrid: Los Sobrinos de la Sucesoria de M. Minúesa de los Ríos.

Mueller, John. 2000. The Banality of 'Ethnic War'. International Security, 25 (1): $42-70$.

Obregón Goyarrola, Fernando. 2005. República, Guerra Civil y Posguerra en el Valle de Cayón y Castañeda (1931-1950). Santander: the author, in collaboration with Parlamento de Cantabria and Braña. 
Obregón Goyarrola, Fernando. 2007. República, Guerra Civil y Posguerra en los Valles de Liébana y Peñarrubia (1931-1957). Santander: the author, in collaboration with Parlamento de Cantabria and Braña.

Obregón Goyarrola, Fernando. 2009. República, Guerra Civil y Posguerra en los Valles de Pas (1931-1950). Santander: the author, in collaboration with Parlamento de Cantabria and Braña.

Olson, Mancur. 1971. The logic of collective action: public goods and the theory of groups. Harvard University Press.

Peters, Krijn, and Paul Richards. 1998. "Why We Fight": Voices of Youth Combatants in Sierra Leone. Africa, 68 (2): 183-210.

Preston, Paul. 2007. The Spanish Civil War: Reaction, Revolution, and Revenge. Revised. New York: W.W. Norton.

de Puente Fernandez, Leonor. 1992. Transformaciones Agrarias en Cantabria, 18601930. Santander: Universidad de Cantabria.

Raleigh, Clionadh, Andrew Linke, Håvard Hegre, and Joakim Karlsen. 2010. Introducing ACLED: An Armed Conflict Location and Event Dataset. Journal of Peace Research, 47 (5): $651-660$.

Saíz Viadero, J. 1979. Crónicas sobre la guerra civil en Santander. Santander: Institución cultural de Cantabria.

Salas Larrazábal, Ramón. 1973. Historia del ejército popular de la República. Madrid: Editoria Nacional.

Scott, James C. 2009. The Art of Not Being Governed: An Anarchist History of Upland Southeast Asia. New Haven: Yale University Press.

Shils, Edward A, and Morris Janowitz. 1948. Cohesion and Disintegration in the Wehrmacht in World War II. Public Opinion Quarterly, 12 (2): 280-315.

Solar, David. 1996. La guerra civil en Santander. In La campaña del Norte (abril-octubre 1937), pp. 74-87. Barcelona: Folio.

Solla Gutiérrez, Miguel. 2006. La Guerra Civil en Cantabria: (julio 1936-agosto 1937) Política y Administración. Ph.D. Dissertation. Santander: Universidad de Cantabria.

Solla Gutiérrez, Miguel. 2005. La sublevación frustrada: Ios inicios de la Guerra Civil en Cantabria. Santander: Universidad de Cantabria.

Staniland, Paul. forthcoming. Between a Rock and a Hard Place: Insurgent Fratricide, Ethnic Defection, and the Rise of Pro-State Paramilitaries. Journal of Conflict Resolution.

Stouffer, Samuel A., Arthur A. Lumsdaine, Marion Harper Lumsdaine, Robin M. Williams, M. Brewster Smith, Irving L. Janis, Shirley A. Star, and Leonard S. Cottrell. 1949. The American Soldier. Princeton: Princeton University Press.

Thomas, Hugh. 1994. The Spanish Civil War. 4th ed. New York: Touchstone.

Tilly, Charles. 1992. Coercion, Capital and European States: AD 990-1992. Cambridge: Cambridge University Press.

Toca, Ángel. 2005. La introducción de la gran industria química en España: Solvay y su planta de Torrelavega (1887-1935). Santander: Universidad de Cantabria.

Weinstein, Jeremy M. 2007. Inside Rebellion: The Politics of Insurgent Violence. Cambridge: Cambridge University Press.

Weitz, Mark A. 2005. More Damning than Slaughter: Desertion in the Confederate Army. Lincoln: University of Nebraska Press.

Wickham-Crowley, Timothy. 1993. Guerrillas and Revolution in Latin America: A Comparative Study of Insurgents and Regimes Since 1956. Princeton: Princeton University Press. 